\title{
THE ENFORCEMENT OF FEDERAL STANDARDS IN GRANT-IN-AID PROGRAMS: SUGGESTIONS FOR BENEFICIARY INVOLVEMENT**
}

\author{
Edward A. Tomlinson** \\ Jerry L. Mashaw***
}

\section{INTRODUCTION}

Federal expenditures for grants-in-aid have increased tenfold in the last two decades. Total outlays for federal aid programs, which amounted to 2.4 billion dollars in 1951, were estimated at 27.6 billion dollars for fiscal year 1971. ${ }^{1}$ The number and variety of federal assistance programs have also expanded greatly. The most recent OEO catalog of existing assistance programs hists 1019 domestic assistance programs administered by fifty-seven different federal departments and agencies. ${ }^{2}$

Federal grants are of two basic varieties: formula grants and project grants. Formula grants are distributed to all states according to a predetermined formula spelled out in the enabling statute. A state must normally submit a plan for approval by the federal agency administering the program in order to qualify for its share of the funds. Formula grants continue from year to year and provide most frequently for

* This article is based on a report prepared by the authors for the Administrative Conference of the United States. Although the Conference adopted Recommendations similar to those herein suggested, the views expressed in the report and this article are those of the authors and have not been approved or adopted by the Administrative Conference.

** Professor of Law, University of Maryland. A.B., 1961, Princeton University; M.A., 1962, University of Washington; LI.B., 1965, Harvard University.

*** Associate Professor of Law, University of Virginia. B.A., 1962; LL.B., 1964, Tulane University; Ph.D, 1969, University of Edinburgh.

The authors would like to express their appreciation to Joseph C. Kearfott for his valuable assistance in putting this article in its final form.

I Buread of the Budget, Simplifying Feberal Aid to States and Communities 5 (1970). The majority of grant-in-aid dollars have gone to state and local governments and ouly a small percentage to private persons and institutions.

2 Office of Economic Opportunity, Catalog of Federal Domestic Assistance Programs: A Description of the Federal Government's Domestic Programs to Assist the American People in Furthering their Soctal and Economic Progress (April; 1970). A congressional study by Representative William Roth (R., Del.) counted each authorization as a separate program and uncovered 1315 separate federal assistance programs. H.R. Doc. No. 19-177, 91st Cong., 1st Sess. (1969).

[600] 
health, education, and welfare. Because a state which has an approved plan on file with the federal agency is entitled as a matter of right to the continued payment of its share of any funds authorized and appropriated by Congress for the program, formula grants are sometimes referred to as mandatory grants.

Project grants are disbursed to eligible recipients for specific projects on the basis of project applications. Grants for housing, urban development, and environmental improvement are generally of the project variety. Recipients are usually local units of government or private entities rather than states, as in the case of formula grants. Project grants rely on local initiative and local sensing of needs in requesting funds and in following up applications. Often referred to as discretionary grants, project grants are far more flexible than formula grants and allow federal administrators considerable discretion in deciding which project applications deserve funding. ${ }^{3}$

The line between fornula and project grants is often blurred. The Hill-Burton Act, for instance, authorizes HEW to make project grants to public and private hospitals for the construction and nodernization of hospital facilities but contains also a precise formula for apportioning the available funds among the states. ${ }^{4}$ Federal highway, water quality, and many education grants similarly have both formula and project characteristics.

Federal grants have strings attached; these strings are federal standards. They are devices for ensuring that the persons Congress intended to benefit from a grant program actually receive the benefits. Normally, before receiving a federal grant, the prospective recipient must demonstrate that it will comply with federal standards, either in the project application which it must file to become eligible for a project grant or in the plan which it must file to become eligible for a formula grant.

The purpose of this Article is to explore some of the problems which have arisen with respect to the enforcement of federal standards and to recommend certain changes in federal grant procedures. While the dis-

3 For an excellent discussion of the characteristics of project and formula grants and a comprehensive description of the existing federal grant-in-aid system, see ADvisory Comimission on Intergovernmental Relations, Fiscal Balánce in the American Federal System, ch. 5 (1967).

4 Project apphications for local hospitals must be approved by a state agency prior to submission to HEW and must be in conformity with a state plan that has been approved by HEW, 42 U.S.C. \$291d (1970). 
cussion is cast rather broadly, ${ }^{5}$ it is not intended to cover programs directed at stimulating research, personnel development, or demonstration projects and excludes fellowships and other grants which are made primarily for the benefit of the grantee. Rather, we are concerned with grants made to encourage the grantee to engage in or expand programs benefiting third parties, such as welfare recipients, highway users, school children, and the poor who need medical attention. Within that broad category of grant programs, we have focused upon the program of aid

5 Among the principal grant-in-aid programs which would be covered by these recommendations are:

a. Social assistance grants to the states under the Social Security Act for (1) old age assistance, 42 U.S.C. $\$ 301$ et seq. (1970); (2) aid to families with dependent children and child welfare services, 42 U.S.C. $\$ \$ 601$ et seq. (1970); (3) maternal and child health services, 42 U.S.C. $\$ \$ 703$ et seq. (1970); (4) aid to the blind, 42 US.C. $\$ \$ 1201$ et seq. (1970); and (5) aid to the permanently and totally disabled, 42 U.S.C. $\$ 1351$ et seq. (1970). These are formula grants and are administered by HEW, as are education grants under Title I of Elementary and Secondary Education Act of 1965, 20 U.S.C. \$ 214a (1970), and various grants for the construction of libraries, hospitals, and educational and vocational facilities. See generally, 20 U.S.C. (1970) and 42 U.S.C. (1970).

b. Grants and loans on a project basis to local housing authorities for the development and acquisition of low rent public housing, 42 U.S.C. $\$ \$ 1409,1411$ (1970), and for annual contributions to local housing authorities to assist them in achieving and maintaining the low rent character of the public housing, 42 U.S.C. $\$ 1410$ (1970); urban renewal project grants to local public agencies under Title I of the Housing Act of 1949, 42 U.S.C. \$ 1441 et seq. (1970); model cities grants to cities, 42 U.S.C. $\$ 3301$ et seq. (1970); grants to states and localities for the acquisition and preservation of open-space lands, 42 U.S.C. $\$ \$ 1500$ et seq. (1970). HUD administers all of these programs.

c. Highway construction grants distributed to the states, 23 U.S.C. $\$ \$ 101$ et seq. (1970); and urban mass transportation, 42 U.S.C. $\$ \$ 1601$ et seq. (1970), and airport planning and constitution grants, 49 U.S.C. $\$ \$ 1101$ et seq. (1970) distributed to localities and states. Various administrations of DOT distribute these grants.

d. Grants for the construction of waste treatment works, 33 U.S.C. $\$ 1158$ (1970), and for control of air pollution, 42 U.S.C. $\$ 1857$ (c) (1970), to states and localities. The Environmental Protection Agency administers these.

e. Law enforcement grants to the states under Title I of the Omnibus Crime Control and Safe Streets Act of 1968, 42 U.S.C. $\$ \$ 3701$ et seq. (1970). Normally, the federal grant goes to a state crime commission which then approves applications for funds from state and local law enforcement agencies.

f. Block-type grants to the states for public health services under the Partnership in Health Act of 1966, 42 U.S.C. $\$ 246$ (1970).

g. Grants to public and private nonprofit organizations for antipoverty programs, e.g., emergency food and medical services, 42 U.S.C. $\$ 2809$ (1970); legal services, 42 U.S.C. \$2781 (1970); and community action, 42 U.S.C. \$\$2781 et seq. (1970). The Office of Economic Opportunity administers these programs.

l. Grants to state employment security agencies to facilitate employment, see generally 29 U.S.C. (1970); 42 U.S.C. (1970), and to industries and public and nonprofit organizations to provide job training for disadvantaged youth, 42 U.S.C. $\$ 2711$ (1970). The Manpower Administration in the Department of Labor administers these project grants. 
to families with dependent children (AFDC), the federal-aid highways program, and urban renewal.

\section{Federal Standards in the Grant-In-Aid System: The Compliance Problem}

Federal standards take a variety of forms. Some are specific and commit the grantee to a detailed course of action, while others are more general and require only that the grantee adopt certain goals or take into account specified factors when making program decisions. A general form of federal standard is necessarily involved in all federal grant programs, because each program of federal grants-in-aid has been developed for a particular purpose determined by Congress to be of national concern. Federal funds must be spent by the grantee within the confines of the particular, "categorical," assistance program. Welfare funds cannot be spent for the construction of airports, and vice versa. The enforcement of this type of federal standard has not proved particularly difficult. Attempts to spend grant funds outside the scope of a particular assistance program are rare, and the federal government can respond by refusing to release matching federal funds or by seeking restitution of federal funds that have already been so expended.

A more troublesome type of grant standard-and the type with which this Article is primarily concerned-are standards that control how funds are spent within a given category. These standards may be divided conveniently into four overlapping categories. First, there are standards that are statutory or constitutional in origin and that apply to all or to a great number of programs of federal financial assistance. Among the most important of these are Title VI of the Civil Rights Act of $1964,{ }^{\circ}$ which proscribes racial discrimination under any program or activity receiving federal financial assistance, and the National Environmental Policy Act of $1969,{ }^{7}$ which requires all federal agencies to report on and consider the environmental impact of "major federal actions significantly affecting the quahty of the human environment."

A second category consists of statutory standards which, while also

642 U.S.C. $\$ 2000$ (d) (I970). Another similar statutory standard is contained in the Hatch Act, 5 U.S.C. $\$ \$ 1501$ et seq. (1970), which prohibits political activity by state and local employees engaged in federally financed activity.

742 U.S.C. \$ 4332(c) (1970). The term "federal actions" appears broad enough to cover grants-in-aid. Named Individual Members of the San Antonio Conservarion Soc'y v. Texas Highway Dep't, 400 U.S. 969 (1970) (Black, J., dissenting from denial of certiorari); Sive, Some Thoughts of an Environmental Lawyer in the Wilderness of Administrative Law, 70 Colum. L. Rev. 612, 643-51 (1970). 
designed to secure some general federal policy, are found in the grant statutes themselves-frequently in formula grant programs and occasionally in project grant statutes. For example, Congress normally has insisted that each state recipient of formula grant funds designate a single state agency to administer the federally assisted program and observe a merit system for employment in that agency. A common standard for project grants is the requirement that an areawide plan for attacking a particular problem be submitted to the federal agency prior to the approval of any specific grants for projects in that area. ${ }^{8}$

The third and most important group of standards are those statutory standards which apply only to a single grant program or closely related group of programs. For example, states that receive federal highway construction aid must hold public hearings on the routing of highways that affect urban areas ${ }^{9}$ and must take extraordinary steps to preserve parkland. ${ }^{10}$ Similarly, when applying for federal assistance for aid to needy families with dependent children, states must give assurances in their state plans that they will comply with numerous federal standards in operating their programs. These standards include both general requirements, for example, that the AFDC program operate uniformly throughout the state, ${ }^{11}$ and detailed provisions, such as those for disregarding certain earned income of family members. ${ }^{12}$

A fourth and final group consists of federal standards developed by the federal agencies themselves. These standards apply only to particular programs and appear in agency regulations, manuals, handbooks, policy statements, forms, and other materials necessary for program administration. ${ }^{13}$ While the manuals contain many program policies that are advisory only, and thus not enforceable, other administrative requirements are clearly binding on the recipients of a grant. These standards may go beyond what is specifically required in the statute and depend for their validity on the federal agency's general power to adopt rules and regulations in furtherance of the grant program. HUD's Urban Renewal Handbook, for example, contains a myriad of standards which local public agencies must observe in such diverse activities

8 See, e.g., 42 U.S.C. $\S \S 1451$ (c) \& (e) (1970).

923 U.S.C. $\$ 128$ (1970).

1023 U.S.C. $\$ 138$ (1970).

1142 U.S.C. $\$ 602$ (a) (1) (1970).

1242 U.S.C. $\$ 602$ (a) (8) (1970).

13 For a discussion of these various administrative tools, see Skoler, Lynch \& Axilbund, Legal and Quasi-Legal Considerations in New Federal Aid Programs, 56 Geo. L.J. $1144,1153-57$ (1968). 
as acquiring land for the project, entering into contracts for project work, selecting private sponsors to redevelop a project area, and disposing of land acquired for the project. ${ }^{14}$

\section{Why Have Standards in Sucb Profusion?}

It may appear from the mere description of the main categories of federal grant standards that, if there is a problem with the enforcement of federal standards, it is because there are too many of them. The solution to the enforcement problem might, then, be in "federalizing" programs where dominant national interests require national control and in relaxing standards in other programs by techniques such as block grants or special revenue sharing. A partial "federalization" of the AFDC program has been adopted by the House of Representatives in its recent passage of the Nixon-Mills Family Assistance Plan. ${ }^{15}$ The block grant approach is already used in the law enforcement area ${ }^{16}$ and has been proposed for five other areas in the administration's special revenue sharing proposals: transportation, ${ }^{17}$ manpower training, ${ }^{18}$ education, ${ }^{19}$ and urban and rural community development. ${ }^{20}$

14 This sort of standard has figured prominently in recent Supreme Court cases. Thorpe v. Housing Authority, 393 U.S. 268 (1969) (HUD circular requiring conference prior to eviction held binding on local housing authority); Lewis v. Martin, 397 U.S. 552 (1970) (HEW regulation concerning resources available to a needy child held valid).

15 Nixon-Mills Family Assistance Plan, H.R. 1, 92nd Cong,, 1st Sess. (1971); CoNgressional Research Service, Digest of Public General Bimis and Resolutions, 92nd Cong., 1st Sess., pt. 1, at E-2 (1971).

16 This program is administered by the Law Enforcement Assistance Administration, created by the Omnibus Crime Control and Safe Streets Act of 1968, 42 U.S.C. \$ 3711 (Supp. 1972). Revenue sharing amendments were proposed in the Law Enforcement Revenue Sharing Act of 1971, H.R. 5408, 92nd Cong., 1st Sess. (1971). As to the problems of standards generally found in the revenue sharing area, see Berson, Revenue Sharing: An Analysis of Alternative Statutory Approaches, 8 HARv. J. Legrs. 221 (1971); Musgrave \& Pohinsky, Revenue Sharing: A Critical View, 8 Harv. J. Legrs. 197 (1971). See also W. Heller, New Dimensions of Political Economy 147 (1966); J. Pechatan, Federal Tax Policy 229 (1966).

17 Special Revenue Sharing Program for Transportation, H.R. Doc. 92-71, 92nd Cong., 1st Sess. (1971), proposed in the President's Message of March 18, 1971, 117 Cong. Rec. 1750 (1971); U.S. Code Cong. \& AD. News, March 25, 1971, at 254.

18 Manpower Revenue Sharing Act of 1971, S. 1243, 92nd Cong., 1st Sess. (1971).

19 Education Revenue Sharing Act of 1971, S. 1669, 92nd Cong., 1st Sess. (1971). See Kirp \& Yudof, Revenue Sharing and Its Effect on the Poor, 5 Cleartnghouse Rev. 496 (1972).

20 Rural Community Revenue Sharing Act of 1971, S. 1612, 92nd Cong., 1st Sess. (1971); Urban Community Development Act of 1971, S. 1618, 92nd Cong., 1st Sess. (1971). 
Both of these approaches harbor significant difficulties. "Federalization" is rarely possible because of the political, administrative and fiscal ramifications of the historic state and local involvement in these areas. For example, the provisions of the Family Assistance Plan carve out as federal responsibilities only a particular level of monetary support and certain program elements directly related to the provision of employment. A grant-in-aid program for social services to low-income persons, and what is in effect a grant-in-aid program for state supplementary payments, remain, hedged with many of the present AFDC conditions. While block grants give the states greater authority to determine priorities among competing needs in the broad area of the block grant, certain federal standards, such as Title VI and the Hatch Act, must still be complied with. There also may be specific federal standards for individual block grant programs. ${ }^{21}$

The block grant or special revenue-sharing approach might still be ideal were it not for measurement difficulties. The provision of funds from the federal treasury for a particular state, local, or privately run program is largely, if not always, based on a recognition of benefits from that program which are external to the jurisdiction or geographic area in which it will function and of external costs from state, local, or private under-investment in the activity which is to be supported. Ideally then, the federal government might make its grant-in-aid payments to individual grantees on the basis of calculations of the amount of aid necessary to produce an "optimal" level of program output. The only condition on such grants would be that the specified outputs be achieved. The difficulty is that there are no reliable means by which to measure external economies and diseconomies or the amount of aid necessary to produce (in conjunction with whatever level of grantee spending is likely to be forthcoming) optimal levels of output. Perhaps more important is the difficulty of coming up with sensible definitions of the "outputs" themselves which would indicate whether the grant moneys were being appropriately expended. To take the AFDC example, what should the state be asked to produce? Happy children?

21 Similarly, block grants remain subject to general federal standards (e.g., NEPA) and may contain special requirements. For example, state agencies that receive block grants for law enforcement must "pass through" at least forty per cent of the planning money and seventy-five per cent of the action money to units of local governnent. 42 U.S.C. $\$ \$ 3723$ (c) (1970). In addition, no more than one-third of a block grant to a state may be expended for the compensation of personnel. 42 U.S.C. $\$ 3731$ (d) (1970). For an excellent discussion of the structuring of law enforcement block grants, see advisory Commission on Intergovernmental Rejations, Making the Safe Streets Act Work: AN Intergovernmental Challenge (1970). 
Whole families? Low illegitimacy? Productive and self-reliant adults? A percentage reduction in "poverty"? Even if the more easily measured indicators were taken as goals, the establishment of causal relationships between a grant program and a particular and measurable social change would be enormously difficult. ${ }^{22}$

The drafters of federal grant programs thus tend to be driven toward a choice among: (1) the provision of money without standards; (2) the utilization of "goals" or output standards which either make compliance virtually impossible to estimate or which are measurable but poor substitutes for the true purposes of the grant program; (3) "input" requirements which represent the planner's best guess concerning the necessary techniques for producing the desired results. The input standard or condition has usually been chosen. Moreover, it is difficult to make a convincing argument for the general relaxation of the only type of standard which seems feasible. Standards are thought necessary to achieve national goals, and it is in the name of these goals that federal grant-in-aid programs make very substantial redistributions of resources among the states. According to figures developed for the year 1966, seventeen states were in effect the net grantors, and the rest the net grantees, of federal grant-in-aid programs. ${ }^{23}$ It would seem politically irresponsible to make resource shifts of this magnitude without some considerable exercise of control over expenditures. Hence, it is sensible to expect that categorical grant programs with more or less extensive federal standards or conditions will continue for some time.

\section{Perspectives on the Development of Federal Standards}

A brief look at the development of federal standards in the programs of aid to families with dependent children, urban renewal, and federal-aid highways will reveal a central fact concerning federal grant

22 See generally Olson, The Optimal Allocation of Jurisdictional Responsibility: The Principal of "Fiscal Equivalence" in Jonst Economic CoMmtrtee of THE Congress, The Analysis and Evaluation of Public Expendrtures, 91st Cong., 1st Sess. 321 (1969); Mushkin \& Cotton, Systematic Analysis and Grants-in-Aid in the Federal System, in id., at 332 .

23 Ohio Legistattve Service Comemission, Impaact of Federal Grants-in-Aid on Ohio Admonistrative Policies, Staff Research Report No. 90, at 37 (1969). Earlier statistics on (a) per capita grants-in-aid received as a percentage of per capita contributions to grants and (b) on grants received as a percentage of total federal taxes paid revealed that the states' percentages in these two categories varied from New Jersey's 37 per cent to Wyoming's 459 per cent on the first scale and Delaware's 4.41 per cent to Mississippi's 45.78 per cent on the second. Report of the Virginia Commission on Constitutional Government, Federal Grants-in-Aid 67 (1961). 
policies; congressional and administrative development of grant standards has been directed primarily to solving specific problems which have arisen over the hives of the programs. Any proposal for reform must reckon with not only the general, a priori, but also the operationally verified necessity for the provision of federal standards in grant-in-aid programs. Moreover, this discussion, which includes a more "functional" description of the Urban Renewal Program, will give the reader a better feel for the substance of federal grant policies and the nature of the interests and expectations that they may create for program beneficiaries.

\section{Aid to Families with Dependent Children}

Mechanically, the AFDC program operates rather simply: funding is based on an open-ended formula; a state qualifies for grants by the submission of a "plan" which describes or includes the statutory and regulatory provisions governing the state's AFDC program. AFDC grants-in-aid to the states originated as a means for bailing out state systems of public assistance which had collapsed during the early years of the Great Depression. Although originally adopted by a Congress which showed much greater interest in the other titles of the Social Security Act, AFDC has in recent years become virtually synonymous with "welfare" and "the welfare problem." In the process there has been a marked increase in both statutory and regulatory federal standards to which state plans must conform.

Statutory Standards-Although Congress prescribed only general administrative requirements in section 402 (a) of the Social Security Act during the early years of the AFDC program, these requirements are of some importance. ${ }^{24}$ For example, section 402 (a) (1) provides that the

24 A State plan for aid and services to needy families with children must

(1) provide that it shall be in effect in all political subdivisions of the State, and, if administered by them, be mandatory upon them;

(2) provide for financial participation by the State;

(3) either provide for the establishment or designation of a single State agency to administer the plan, or provide for the establishment or designation of a single State agency to supervise the administration of the plan;

(4) provide for granting an opportunity for a fair hearing before the State agency to any individual whose claim for aid to families with dependent children is denied or is not acted upon with reasonable promptness;

(5) provide

(A) such methods of administration .... as are found by the Secretary to be necessary for the proper and effective operation of the plan, and

(B) for the training and effective use of paid subprofessional staff, with particular emphasis on the full-time or part-time employment of recipients and other persons of low income... 
state plan shall be. in effect in all political subdivisions of a state. The provision was designed to avoid the difficulties of state mother's pension laws, which President Roosevelt's Committee on Economic Security had found to be ineffective because of their local option provisions. ${ }^{25}$ The vitality of section 402 (a) (1) has remained undiminished, due to the difficulties that face localities in virtually all public services financing and the need for spreading financial responsibilities to even broader jurisdictions. Similarly, the section 402(a) (5) requirement of a merit system for the selection and advancement of state welfare personnel, enacted in response to notorious abuses experienced between 1935 and 1939, ${ }^{26}$ remains desirable as a means by which the federal government can assure some minimum standards of professionalism in the state's administration of the program it has funded.

In 1939 the first nonadministrative conditions were imposed upon states participating in the AFDC program. Subsection (7), which requires that states take into account the income and resources of a recipient in determining need, was added to eliminate federal funding of some states' practices of making old age assistance grants to all of their elderly citizens. ${ }^{27}$ Subsection (9), also added in 1939, requires that a state plan contain provisions to safegnard the confidentiality of information provided by applicants and recipients to state and local welfare personnel. Although relaxed somewhat in $1951,{ }^{28}$ the provision still protects against the political and commercial use of welfare rolls.

In the early 1960's, major hostilities toward AFDC developed. At

(6) provide that the State agency will make such reports, in such form and containing such information, as the Secretary may from time to time require, and comply with such provisions as the Secretary may from time to time find necessary to assure the correctness and verification of such reports .... 42 U.S.C. $\$ 602$ (a) (1) to (6) (1969).

25 Hearings on HR. 4120 Before the House Comm. on Ways and Means, 74th Cong., 1st Sess. 48 (1935).

26 The Social Security Board had been forced to withdraw funds from Oklahoma, Ohio, and Illinois in the period 1937-38. Some counties in Oklahoma had more people on their public assistance rolls than they had residents; the Illinois financial and accountting procedures were virtually nonexistent; and in Ohio the state Republican leadership had raised grants on the eve of primary elections and used the aid envelopes to distribute campaign propaganda. Hearings on the Social Security Act Amendments of 1939 Before the House Comm. on Ways and Means, 76tl Cong., 1st Sess. $2396-98$ (1939).

27 See A. Altmeyer, The Formative Years of Social Securty 60-61 (1968). Section 402 (a) (7) has been amended to make clear that the consideration of income and resources should include those of any individual living in the home of a recipient whose needs are considered in determining the needs of the recipient.

2842 U.S.C. $\$ 602$ (e) (19) (1970). 
the state and local level these hostilities were manifested by abuses in the application process and the creation of waiting lists for applicants. Congress responded with section 402 (a) (10), which requires that state plans provide for the provision of assistance with reasonable promptness to all eligible individuals. Soon thereafter, however, disenchantment began to appear at the federal level, first in the increasingly articulate belief that AFDC was a disincentive to work and later in the widely expressed fear that welfare fostered an intergenerational cycle of dependency. Amendments to sections 402(a) (7) and (8) responded to the belief that AFDC was a work disincentive by requiring that states disregard certain funds in considering income and resources, thus making it less likely that a recipient would lose benefits were he to secure a job. The fear of a cycle of dependency (coinciding with increased budgetary demands of the Vietnam War) created a major Congressional struggle in 1967 over proposed changes in AFDC. The results were mandatory work training ${ }^{29}$ and a temporary freeze on funds for deserted children. ${ }^{\mathbf{3 0}}$

Regulatory Conditions-Federal regulations governing grant programs are often criticized for invading the proper prerogatives of the grantees, for being outside the authority of the grantor agency, and for contributing to the problem of grantee noncompliance by their detail and complexity. A review of the development of the AFDC regulations suggests a somewhat different picture. Like the statutory standards, regulatory conditions in AFDC have largely been responsive to the practical difficulties of implementing federal policies in the face of less than enthusiastic grantee acceptance of those policies.

Regulatory requirements implementing the conditions of section 402 (a) do tend to develop over time from broad and abstract requirements to more specific, objective, and measurable standards. But the trend is neither inflexible nor without justification. The consistent failure of state and local administrators to administer the AFDC program in conformity with basic federal policies, expressed in general terms, often leads to the promulgation of very specific rules in an attempt to secure compliance. ${ }^{31}$ Moreover, because the regulations must

2942 U.S.C. $\$ \$ 630-44$ (1970).

30 The freeze was imposed by the Act of Jan. 2, 1968, Pub. L. No. $90-248, \S 208,81$ Stat. 894. It was partially lifted by the act of Jan. 28,1968 , Pub. L. No. 90-364, $\$ 301$, 82 Stat. 273; and was repealed by the Act of July 11, 1969, Pub. L. No. 91-41, $\$ 3,83$ Stat. 45.

31 See, e.g., King v. Smith, 392 U.S. 309 (1968) where the Court found that Alabama (in a manner typical of many states) systematically excluded otherwise eligible children 
be designed to foster general federal policies (such as due process and equal protection), general program policies (such as the policy that aid be available to all eligible persons), and specific program goals, certain regnlations (such as the ones carrying out the amendments to section 402 (a) (7) requiring a recipient's income and resources to be considered in determining need) may be more detailed than would be necessary solely to ensure the pursuit of any individual program goal. ${ }^{32}$

On the other hand, compliance problems may sometimes arise because of too few regulations rather than too many. There is evidence, for example, that a considerable degree of state nonconformity was engendered by HEW's reluctance to come forward with specific regulations concerning what would be an acceptable amendment to state plans under section 402 (a) (23)..$^{33}$ And bowing to considerations of "federal balance" and state prerogatives, ${ }^{34} \mathrm{HEW}$ does not always issue detailed rules, even when noncompliance with general regulations is discovered.

\section{Urban Renewal}

The most important federal standards in the urban renewal program are requirements which condition grantee operations prior to the commencement of project execution; once land acquisition or demolition begins, the costs involved in making any changes to secure compliance with federal standards increase enormously. The planning and application process is thus the key element of the program for federal grant purposes.

Nature of the Application Process-A conventional urban renewal project involves the rehabilitation or clearance and development of a blighted, deteriorated, or slum area. The project is planned and exe-

on the basis of highly conjectural income from the paramour of their mother. The Alabama practice conflicted with basic policies of the AFDC program concerning the definition of dependency and the provision of aid to all eligible individuals. Hence, the Department was forced to draft very specific rules on income attribution to guide state practice. Similar developnents can be traced in a number of other areas including fair hearings, income distegards, confidentiality, standards of promptness in eligibility determinations, and a plethora of additional practice issues surrounding the provision of aid to all eligible individuals.

32 Cf. Lewis v. Martin, 397 U.S. 552 (1970).

33 See Rabin, Implementation of the Cost-of-Living Adjustment for AFDC Recipients, 118 U. P. L. REv. 1143 (1970). HEW has also taken considerable time to promulgate regulations on fair hearings after Goldberg v. Kelly, 397 U.S. 254 (1970).

34 See, e.g., 45 C.F.R. $\$ 205.120$ (statewide operation provision of $\$ 402$ (a) furthered by only a broad and vague regulation). 
cuted by a local public agency (LPA) which contracts with HUD for federal financial assistance in the form of advances, loans, and grants. The LPA selected by a city to run an urban renewal project must file with HUD a survey and planning application for the project. If the application is approved, HUD reserves a grant for the project out of the undistributed moneys in the Urban Renewal Fund and advances federal funds to the LPA for planning purposes. The initial planning stage lasts on the average about fourteen months, ${ }^{35}$ and it culminates in a loan and grant application. This application normally consists of two parts, ${ }^{36}$ the first of which is submitted prior to approval by the locality's governing body to allow the LPA to gain HUD's acceptance of the urban renewal plan before entering the political fray for the city's approval. The great majority of the information and supporting data on the project accompanies part I. Part II merely updates this information and includes the locality's approval of the plan. Although the application forms themselves are quite brief, the LPA also must submit a number of accompanying reports. The most important of these reports establish through relevant factual data that the project meets federal requirements. Once HUD approves the part II application, it enters with the city into a loan and grant contract for the project. While the six to nine years that typically are necessary for execution mean that changes in the plan will probably be needed, HUD approval is required in only a few cases. ${ }^{37}$ The LPA will be required, however, to verify its compliance with federal standards during the execution stage. ${ }^{38}$

Congress recently established a new method of planning and funding urban renewal projects designed to provide greater flexibility. ${ }^{39} \mathrm{Un}$ der the Neighborhood Development Program (NDP), a commumity's renewal activity covers one or more urban renewal areas and is funded

35 Bureau of the Budget, Simplifying Federal Aid to States and Communities 9-10 (March, 1970). This stage has been shortened considerably by major reductions in the required documentation of the planning process announced by HUD in February 1970. Departament of Housing and Urban Development, Urban Renewal Handboak, RHA 7200.1, (February, 1970) [hereinafter cited as URBAN RENEwaI HANDBOoK].

36 The two stage process is now optional and the LPA may combine Parts I and II into a single application. URBAN RENEWAL HANDBOOK, RHA 7206.1, ch. 2 (February, 1971).

37 For example, where there is a change in project boundaries, and therefore a need for more money, the LPA must file an amendatory loan and grant apphication.

38 HUD has recently simplified this process in several areas by allowing certificates proclaiming compliance to be submitted in lieu of factual data. URBAN RENEwaL HANDBOoK, RHA 7200.1 (February, 1971).

3942 U.S.C. $\$ \$ 1469-1469$ (c) (1969). 
by HUD on an annual basis rather than through the reservation of a single project grant. The LPA must specify annually the urban renewal activities which it intends to implement during that year. By not committing funds years in advance and by requiring continued planning, NDP seeks to lessen the danger that a plan will become obsolete before it can be fully implemented. ${ }^{40}$

Federal Standards in Urban Renerwal-Many of the standards that accompany urban renewal grants are budgetary and program controls designed to ensure that the LPA operates efficiently. The more important standards for purposes of this Article, however, are those intended to protect the interests of third parties or to further national housing goals. The following are examples of three such standards which raise serious enforcement problems. While there are other standards governing issues which raise equally difficult problems, ${ }^{41}$ these three will best convey an idea of the problems which the recommendations of this Article are designed to ameliorate.

a. Workable Program Requirements. In order to be eligible for advances, loans, or grants for urban renewal, a locality must have a certified "workable program for community improvement." HUD certifies programs for two-year periods. A workable program, which is defined by HUD as a "[c]ommunity's own plan of action for eliminating and preventing slums and blight," must demonstrate that a community is making satisfactory progress in four essential areas: housing codes and housing code enforcement, overall community planning, relocation of persons and businesses displaced by governmental action, and meaningful citizen involvement in planning and executing HUDassisted programs. ${ }^{42}$ The adequacy of a community's workable program may be challenged at the time it is filed with HUD for certification or recertification or at the time the community files a survey and planning or a loan and grant application. In addition to the above, there is the further requirement that the planning section of the workable

40 Participation in NDP is voluntary, but a significant number of the large cities have taken advantage of this alternate method of urban renewal.

41 E.g., eligibility of the project area, URBAN RENEwAL HANDBOoK, RHA 7205.1 (February, 1971); eligibility of a project area for clearance and redevelopment, 42 U.S.C. \$ 1460 (c) (1970). URBAN RENEwal HaNDBook, RHA 7207.1, cl. 1 (February, 1969), or for rehabilitation, URBAN RENEWAL HANDBOOK, RHA 7210.1, clr. 1, 6 (February, 1971); types of public liearings, 42 U.S.C. $\$ 1455$ (d) (1970), URBAN RENEwAI HANDBooK, RHA 7206.1, clr. 3 (February, 1971); and land acquisition policy, 42 U.S.C. $\$ 4651$ (1970).

12 Department of Housing and Urban Development, Workable Program fas COMMUNITY IMPROVEMENT HANDEOOK, RHA 7100.0. 
program be of sufficient scope and content to permit evaluation of the need for an urban renewal project. This final standard must be met at the time of the part I loan and grant application for the project, and HUD must determine that the project is in accord with the general community plan in the workable program. ${ }^{43}$

b. Minority Group Considerationss. In addition to the requirements of Title VI of the Civil Rights Act of 1964,44 HUD requires that the boundaries of a project area be determined without regard to race, creed, color, or national origin of the residents. ${ }^{45}$ Even more important, HUD requires the LPA to consider minority group interests in selecting and planning an urban renewal project. The project must contribute to reduced concentration of minority group families and to greater equal housing opportunity wherever feasible. It must not result in a reduction in the supply of dwellings in the community available to minority group families, and representative minority group leadership must be consulted in planning the project. Whenever a project will result in a substantial net reduction in the housing available to minority group families in the project area, the locality must compensate for the reduction by providing them with housing not previously available to them elsewhere in the locality. ${ }^{46}$ The LPA must submit with part I of its loan and grant application a report on minority group considerations explaining how it has satisfied these criteria.

c. Relocation of Displaced Individuals and Families. The basic relocation requirement is that individuals and families displaced from an urban renewal area have available "decent, safe, and sanitary dwellings equal in number to the number ... of the individuals and families displaced and reasonably accessible to their places of employnent." ${ }^{47}$ The relocation housing must be in the urban renewal area or in other areas not generally less desirable and at rents and prices within the financial means of the displaced individuals and families. In addition, the LPA must develop and submit a comprehensive program of relocation assistance for displaced individuals, families, and businesses. A relocation report must contain the LPA's relocation program and fairly

43 Urban Renewal HandBook, RHA 7204.1, ch. 1 (August, 1969).

44 See note 6 supra.

45 URBAN ReNewal HaNdBooK, RHA 7207.1, ch. 1 (February, 1969).

46 Id.

4742 U.S.C. $\$ 1455$ (c)(1) (1970). The Uniform Relocation Assistance and Real Property Acquisition Policies Act of 1970, 42 U.S.C. $\$ 4601$ et seq. (1970) does not repeal this section. The substantive standard on the availability of relocation housing appears to be the same under both laws. 
specific data on the housing needs of displaced families and the housing resources available to them. This information should demonstrate that it is feasible to relocate displacees into standard housing that meets the statutory requirements. ${ }^{48}$

Additional relocation standards must be met at the execution stage of an urban renewal project. The LPA must interview all site residents to be displaced and supply them with an information statement on the availability of relocation assistance and payments. ${ }^{49}$ The LPA must also keep records on the relocation of displaced individuals and families and continue to provide them relocation assistance until they are relocated in standard housing. In addition, the Secretary must require, prior to actual displacement, satisfactory assurances by the LPA that decent, safe, and sanitary housing is available for the relocation of each such individual or family. Finally, Congress provided in the Housing and Urban Development Act of $1969^{50}$ that HUD must review by December 24, 1970 and every two years thereafter each locality's relocation plan and the locality's effectiveness in carrying out that plan. This statute reflects the increased concern in Congress over HUD's failure to enforce adequately the basic standard in 42 U.S.C. $\S 1455$ (c)(1) that relocation housing be available for persons displaced by urban renewal projects.

\section{The Federal-Aid Highways Program}

Statutory Standards-The federal government's participation in road building has since 1921 been based on the view that the primary national interest involved is the provision of a linked system of toll-free roads for the movement of persons and goods in interstate commerce. ${ }^{51}$ Hence, aid is available only to the extent that a project is recognized as a part of a federal-aid highway system, ${ }^{52}$ and the major funding effort has been made with respect to the primary system which carries largely inter-urban transportation. ${ }^{53}$ In addition, the states are required to establish a state department of highways with sufficient authority to carry out the duties imposed by federal legislation. ${ }^{54}$

Beginning in 1958 with the requirement that projects by-passing or

4842 U.S.C. $\$ 1455$ (c) (1) (1970); URBAN RENEWAL HANDBOOK, RHA 7212.1, ch. 2 (February, 1971).

49 URBAN RENEWAL HANDBook, RHA 7212.1, ch. 3, \$ 1 (February, 1971).

5042 U.S.C. $\$ 1455$ (c) (3) (1970).

5123 U.S.C. $\$ 301$ (1970).

5223 U.S.C. $\$ \$ 103-05(1970)$.

6323 U.S.C. 55101 (b), 103 (a)-(d) (1970); 23 U.S.C. $\$ 103$ (e) (1) (1970) (Supp. 1972).

5423 U.S.C. $\$ 302(1970)$. 
going through towns be approved for federal aid only on certification that opportunity for public hearing has been afforded to interested parties, ${ }^{55}$ a series of interrelated standards concerning comprehensive transportation planning, local control, citizen participation, environmental quality, relocation housing, and social values have been grafted onto the federal-aid highways program. The standards respond to the increasing realization that federally aided highway programs have produced a series of changes ranging from massive reorientations in urban land use to degradation of atmospheric conditions, erosion of the local tax base, increased shortages of low-income housing, and shifts in state and local political power.

Many of these standards are analogous to those found in urban renewal. While local governing bodies do not have veto power over highway plans as they do over plans for urban renewal, their views must be considered, ${ }^{56}$ and there must be cooperative planning between states and localities. ${ }^{57}$ Projects must be consistent with area planming objectives, ${ }^{58}$ and projects within Standard Metropolitan Statistical Areas must be based on continuing, comprehensive transportation planning. ${ }^{59}$ As with urban renewal, public hearings are required at times when the state highway department retains flexibility to respond to the views presented. ${ }^{60}$ Finally, the relocation processes in the two areas are both governed by the Uniform Relocation Assistance and Land Acquisition Policies Act. ${ }^{\text {t1 }}$

Some of the more important recent standards involve social, economic, and environmental considerations. A state highway department must certify that it has considered in its location decision for a federalaid project "the economic and social effects of such a location [and] its impact on the environment." 62 This certification must be accompanied by a report indicating the consideration given to the various effects and alternatives. ${ }^{.3}$ In addition, federal-aid highway projects

5523 U.S.C. $\$ 128(1970)$.

5623 U.S.C. $\$ 143$ (1970) (applies only to Standard Metropolitan Statistical Areas).

5723 U.S.C. $\$ 106(1970)$.

6823 U.S.C. $\$ 128(1970)$.

5923 U.S.C. $\$ \$ 134,307$ (1970).

60 23 U.S.C. $\$ 128$ (1970); Federat Highway Administration, Policy and Procedure MEMorandum 20-8, 23 C.F.R. 1-38 App. A (1972).

6142 U.S.C. $\$ \$ 4601$ et seq. (1970). There are some differences in the two procedures due to the fact that 23 U.S.C. $\$ 133$ (1970) makes certain additional relocation requirements. Moreover, the regulations issued by the two agencies are not the same.

6223 U.S.C. $\$ 128(1970)$.

6323 U.S.C. $\$ 135(1970)$. 
must comply with the requirements in the National Environmental Policy Act of 1969 inter alia of environmental statements and consultation with all federal agencies having authority or expertise with respect

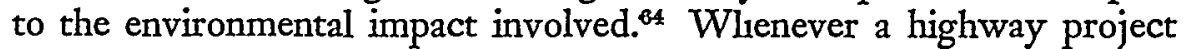
contemplates taking property from any park, recreation area, or wildlife refuge of national, state, or local significance (as determined by the responsible jurisdiction) or from a historic site similarly identified, it may do so only if there is no "feasible and prudent alternative," and then it must utilize "all possible planning" to minimize harm. ${ }^{85}$ Federal legislation also promotes landscaping and scenic enhancement by providing that three per cent of a state's apportionment must be spent for this purpose. ${ }^{68}$

\section{Comparison of Standards Under the Three Programs}

It is apparent that, despite certain similarities, there are fundamental differences in the standards found in the three programs. With some obvious exceptions, the AFDC requirements tend to be substantive, that is, to require that a state plan reflect certain essential elements which make up an AFDC program (need standards, social services, work incentive programs and so on), whereas the federal-aid highway standards are largely procedural; they require that state highway departments coordinate with certain other agencies, consider certain questions, or have certain processes for citizen participation. Urban renewal standards tend toward the procedural in this sense, though there are important standards, such as those which establish whether an area is to be accorded rehabilitation or clearance and redevelopment treatment, ${ }^{B T}$ which reflect essential substantive policies.

Does one or the other type of standard have a better chance of being followed consistently by the grantees and therefore producing fewer compliance problems? The answer is clearly "yes." Procedural standards are almost certainly easier to enforce by the simple strategem of requiring the submission of particular forms and certifications showing that all the required consultations have been had, hearings held, and considerations considered. Moreover, because the procedure has to be

\footnotetext{
6442 U.S.C. $\$ 4321$ (1970) (Supp. 1972); Exec. Order No. 11514, 35 Fed. Reg. 4247 (1970).

6523 U.S.C. $\$ 138$ (1970).

6623 U.S.C. $\$ 319$ (b) (1970).

${ }^{67}$ See note 41 supra.
} 
repeated for each new project, the required routine is likely to become fairly easily established in the state or local agency.

Should one then conclude that procedural standards are appropriate for all grant-in-aid programs, including programs like AFDC? We think not. The standards in the various grant programs are necessarily different because they deal with different issues, personnel, and beneficiaries. For example, the environmental effects of a particular highway location or the relocation problems of a particular urban renewal project are not ones that can be dealt with in the same specific manner as can the amount of earned income that is to be disregarded in figuring the needs of a welfare recipient. Moreover, while the provision of a required process for considering environmental or relocation impacts which involves all the interested parties in the decision may be sufficient to serve the national interest, federal policy is not likely to be furthered by a provision that welfare recipients individually or as a group negotiate with the state concerning the amount of earnings disregard that will provide them an incentive to work. In AFDC the ability to provide concrete guidance combines generally with a felt necessity for doing so, while the highway and urban renewal standards refiect a process orientation which may not be sufficient but is often necessary. The form of the standard must be tailored to the needs of the particular pohicy and the ability of the policy-maker to develop sensible a priori criteria. A single style of condition will not suffice for all programs or, indeed, for all aspects of a single program.

\section{The Need for Better Enforcement of Federal Standards}

The program standards summarized above reflect a considerable responsiveness in Congress and the agencies that administer federal grant programs to findings that federally funded programs are producing inappropriate results. To a certain degree, for example in AFDC, this responsiveness has taken the form of increased protections or expanded programs for existing classes of beneficiaries. In other instances, notably the highways and urban renewal programs, solutions to emerging problems have required the recognition of new interests and hence new classes of beneficiaries.

There are growing indications, however, that the grantees and beneficiaries of many grant programs are without recourse in the face of autocratic decisions or indifference by federal administrators, who are unaccountable to a popular constituency and may be insensitive or 
unsympathetic to local problems and conditions. ${ }^{68}$ The position of the putative beneficiary of a grant program or protective condition is of particular concern. His interests depend upon the enforcement of federal standards and may be ignored in the accommodation of grantor and grantee interests through informal processes in which the beneficiary does not participate. Moreover, the effectuation of federal policy depends in large part upon whether these beneficiaries are secure in the enjoyment of their claims to benefits, services, or procedural protections.

\section{The Agency Enforcement Effort}

It is common knowledge that federal grantor agencies have had less than total success in enforcing important federal standards in a number of major grant-in-aid programs, and there is considerable evidence that the federal enforcement effort, with respect to some standards, has been seriously deficient. The United States Commission on Civil Rights recently conducted an exhaustive study of the federal government's enforcement of the Title VI standard of nondiscrimination in federally assisted programs. The Commission found that the enforcement effort lacked uniformity and consistency and demonstrated a reluctance to apply available sanctions in cases of noncompliance. ${ }^{69}$ The General Accounting Office has documented on several occasions HUD's failure to obtain compliance with the federal standard that adequate relocation housing be available for persons displaced by an urban renewal project. ${ }^{70}$ No doubt the standards of nondiscrimination and of adequate relocation housing are among the most difficult to enforce, but the failures in these areas are discouraging; these standards reflect vital national concern and vital beneficiary interests. In other areas, federal agencies have not sufficiently articulated, much less enforced, federal standards that are crucial to grant-in-aid programs. ${ }^{71}$

There are a number of reasons for the failure to enforce federal grant-in-aid requirements. At the most general level, the reason is that agencies are with few exceptions not "enforcement oriented." Grant-

68 Cahn \& Cahn, The New Sovereign Immumity, 81 HaRv. L. Rev. 929 (1968).

69 United States Commission on Civil Rights, Fideral Civil Rights Efforts 803-09 (1970).

70 Tondro, Urban Renewal Relocation: Problems in Enforcement of Conditions on Federal Grants to Local Agencies, 117 U. PA. L. Rev. 183, 194-95 nn. 79-86 (1968). See also E. Cahi, I. Eichenberg, \& R. Romberg, The Legal Lawbreakers: A Study of the Nonadministration of Federal Relocation Requiremenis (1970).

71 See, e.g., W. Bell, Aid to Dependent Chimdren 186-94 (1965). 
in-aid programs are, after all, meant to be cooperative efforts. The posture of the federal agency toward its grantees is not generally that of a referee calling fouls, but that of a coach giving support in the form of cash and expertise. Moreover, there are strong incentives for low-visibility conflict and accommodation. The mainstay of the federal enforcement arsenal, the fund cut-off, may have adverse effects. The remedy, if it has to be applied, helps no one and torpedoes the program. And while grantees may comply when threatened in a credible fashion with fund cut-off, ${ }^{72}$ the sanction raises the political stakes in any federal grantor/state or local grantee confrontation enormously. Federal grant persounel are hesitant to play, or play often, in high-ante games. Furthermore, sharp delineation of federal versus state positions and stringent efforts to exact compliance are likely to cause control of the conflict to shift from the hands of agency professionals to the hands of politicians. ${ }^{73}$ If this happens, the results will be unpredictable and from the program professional's viewpoint may be disastrous.

These general attitudes have a pervasive effect on the internal enforcement mechanisms within grantor agencies. A review of the techniques by which conformity issues are discovered, processed, and resolved in the AFDC program is instructive. Section 604 of the Social Security Act provides a formal hearing procedure for determination that a state is not in compliance with the requirements of section 402 (a) and pertinent regulations. This procedure is initiated by the Secretary and concerns conformity issues specified by him, but affected private parties may participate as interveners. ${ }^{74}$ The Regional Offices of HEW employ a number of formal and informal review techniques, including the receipt of complaints from private parties, to detect conformity issues for ultimate resolution or prosecution through the formal con-

72 See, e.g., Arizona State Dep't of Pub. Welfare v. HEW, 449 F.2d 456 (9th Cir. 1971); Connecticut State Dep't of Pub. Welfare v. HEW, 448 F 2d 209 (2d Cir. 1971). The fund cut-off or the threat thereof has also proved effecrive in achieving desegregation in many southern school districts receiving federal funds under Title $I$ of the Elementary and Secondary Education Act of 1965. 20 U.S.C. $\$ 241 \mathrm{j}$ (1970). See Carter, Equal Educational Opportanity for Negroes-Abstraction or Reality, 1968 U. Ir. L. F. 160, 174-76.

73 A classic example of this type of confrontation occurred in 1963 when HEW refused to provide federal funds, under what is now the AFDC program, for Michigan's plan to provide assistance to needy children with an unemployed parent because Michigan's definition of "unemployment" conflicted with federal law. This struggle quickly deýeloped into a personal feud between Governor Romney and Assistaut Secretary Cohen of HEW. G. Steiner, Soclat Insecurity: The Polimcs of Weifare 101-07 (1966). Similar problems have recently arisen in California.

74 National Welfare Rights Organization v. Finch, 429 F.2d 725 (D.C. Cir. 1970). 
formity-hearing procedure. Because everyone connected with the administration of the AFDC program admits that there are still widespread compliance problems, the procedures are obviously not wholly adequate to ensure compliance. They do not work for a number of general and specific reasons.

\section{Regional Office Attitudes, Structure, and General Compliance Procedures}

Compliance and enforcement have not proved successful in the AFDC program because HEW has not given them priority. Until 1968 regional offices had no delegated authority to negotiate with states concerning compliance issues. They could merely identify such issues and refer them to the central office. According to the longtime director of the regional office studied for purposes of this article, Region III, fifty-seven compliance issues were settled in one month when that regional office was delegated authority to enter into negotiations and settlements. At least half of those issues had existed for more than two years. The long history of nonemphasis on compliance and enforcement, however, has left an attitude within the relevant bureau of the regional office, the Assistance Payments Staff of the Social and Reliabilitation Service (SRS), that the principal responsibility for compliance and enforcement lies with the state agency. The basic approach of the regional office is preventative; the regional office sees its main function as giving information to the states concerning requirements and target dates, providing teclinical assistance on the drafting of language, and giving other assistance and advice concerning state progranus which is designed to obviate the identification of conformity issues. Everyone in Assistance Payments talked to for the purposes of this Article believes that the chief function of the employees of that administration should be program development and not program evaluation or enforcement.

\section{The Steps in the Enforcement Process}

A number of people in the Region III office of HEW have some responsibility for ensuring compliance with federal standards. The Executive Assistant to the Regional Commissioner is designated as the compliance officer, but, in fact, he inherits the conformity issue only after it has been identified by the personnel on the Assistance Payments Staff. If he agrees with Assistance Payments that there is a conformity 
problem, he then refers the matter to the Regional Commissioner who: sets up a docket. From this point the Regional Commissioner and his staff have, at least hypothetically, six months to negotiate with the state in order to settle the issue. If at the end of that period no satisfactory progress has been made toward compliance, the issue is referred to the central office.

The key personnel in the compliance efforts of the regional office are really those on the Assistance Payments Staff. In Region III there are now two employees in Assistance Payments (or "Income Maintenance" as it has recently been renamed). They make all the initial decisions concerning the conformity of state plan materials with federal requirements and concerning whether there is in fact compliance in "practice" with the federal standards. They also make an initial attempt to correct problems as they arise. Information concerning the conformity or nonconformity of state public assistance systems with federal requirements comes to the Staff through the submission of state plan material by the states, administrative reviews of state systems, informal contacts with the states, citizens' complaints, required statistical reporting from the states, quality control reports, and federal audits.

State Plan Review-The state plan consists either of all the statutory and regulatory materials which govern the operation of the state public assistance system or a descriptive summary of these materials. ${ }^{75}$ Every amendment to this material is forwarded to HEW for an opimon as to whether it complies with federal requirements. At the regional office level the SRS can accept state plan materials but cannot reject them as nonconforming. Changes in a state's program, and hence in its state plan, are not prevented from going into effect by a determination of nonconformity by HEW. HEW's only remedy is to withdraw federal matching funds after a conformity hearing scheduled by the central office. If the SRS personnel consider a state plan amendment to be nonconforming, they will refer it to the central office through the procedure outlined above. ${ }^{78}$

Because of the lack of personnel and the large number of submissions, a large amount of potentially nonconforming state plan material can slip by without objection. A recent report on compliance issues

75 There is now also a limited use of the proclaimer system for new or revised requirements for state plans.

76 In many cases the states submit draft material to SRS for an opinion on whether, if adopted, the material would be conforming. 
outstanding with respect to state plans lists sixty-nine assistance payments issues which have been reported to the central office. ${ }^{77}$ But persons active in national welfare rights organizations or in legal services offices in virtually any state can provide a list of numerous provisions in almost any state plan about which serious questions of compliance could be raised but have not been. Indeed, most of the issues of noncompliance with federal standards that have been raised in litigation have never been formally identified as compliance issues by $\mathrm{HEW}{ }^{78}$

To the extent that the regional office identifies state plan issues on the basis of submittals by the state-and it would seem that this is the usual manner in which they are discovered-the new proclaimer system, whereby the states will merely check off the existence of various provisions in their state plans on a standardized form, will make it increasingly difficult for the regional office to make comphance determinations. But in the final analysis, this may not be too important. A look through the listed issues of nonconformity in the latest SRS compliance report reveals a catalogue of relatively trivial issues concerning the organization of community services units, fornuation of advisory groups, and so forth. The core issues of eligibility that surface continually in litigation are not being discovered and reported through the review of state plans anyway.

Administrative Review-The major technique which should give the regional office information concerning nonconformity in practice is administrative review. The Program Staff Manual Part 5, Administrative Review of State and Local Operations, lists the objectives of administrative review as providing a factual basis for assuring state adherence to federal requirements, providing information on state administration to serve as a factual basis for reappraising present policies at the federal level, and providing a factual basis for regional office advice and assistance to the state agency on the development of its total program. According to the Manual, reviews are to be made periodically of the application process, fair hearings, foster care, intermediate care facilities, money payments, and the simplified method of determining

77 Departasent of Health, Education and Welfare, Summary of Compliance, Issues by States by Program (report for quarter ending Dec. 31, 1971). These sixtynine issues do not, of course, include all of the issues uncovered by the regional offices. Some are not yet reported as compliance issues because the preliminary investigations are still in progress.

78 Of course, it is impossible to determine the extent to which this failure to raise issues results from failure to see them as distinguished from an initial resolution of the potential issues in favor of the conformity of the state plan when submitted. 
eligibility. A review is to be made in each of these areas approximately every four years, subject to modification due to the availability of regional staff and resources, varying circumstances, individual states, and so forth.

In Region III administrative review has virtually been modified out of existence. Since 1961 there has apparently been one review of state quality control systems, one review of social services, and a congressionally requested review of simplified eligibility methods. At one time, approximately between the years of 1948 and 1950 , the administrative review technique seems to have been widely used. In 1950, however, the system was abandoned as too costly.

Currently, Region III has no specific timetable for carrying out reviews. Instead, it uses a review when a particular problem, usually one that has reached crisis proportions, is brouglit to its attention. ${ }^{70}$ Two reasons for thus limiting the use of administrative review are advanced, the lack of staff and the use of the quality control system. Neither of these reasons seems adequate. During most of the 1960's, the Social and Rehabilitation Service staff in the Region III office was quite large, but very few reviews were done. Moreover, the quality control system is an extremely poor substitute for administrative review. Quality control focuses only on the eligibility aspects of the program, and it provides few clues to local practices, because the sample in any locality is small and unidentified.

Informal Contact-The Director of the Assistance Payments Staff visits each state in her region for two or three days every six weeks. On these visits she holds informal discussions and formal meetings with state agency personnel concerning potential compliance problems suggested by other information received. As an approach for discovering compliance issues, the visitation method is probably best suited to state administered programs. In those programs the state office generally has good knowledge of what is going on in the local offices. In states where local offices are semi-autonomous, the regional office personnel can learn no more than the state agency itself knows, which may be very little. The state visits are, however, probably a useful tool, because they at least remind the states that HEW has not forgotten about them and about the requirement that they conform to federal standards.

Citizen Complaints-The regional offices of HEW employ a highly

79 For example; a review of welfare applications was recently performed in three Virginia counties because a series of complaints had been received from cities alleging maladministration by local welfare officers. 
informal but reasonably consistent complaints procedure. Whenever a complaint is received, the complaining party receives a response within seven days. If the complaint concerns a local practice, the regional office will usually refer the complaint to the state agency on the theory that the states are primarily responsible for correcting local practices. Where the question is one of eligibility, the regional office will suggest to the complainant that he continue to deal with the local office and also inform him of his right to a state appeal or fair hearing. The regional office's response will also suggest that the person write back if satisfaction from the state is not achieved. But if the issue involves a state practice or policy, the regional office will take the appropriate action itself. Also, in some cases involving local practices where the state does not seem to be making any progress in solving the problem, the regional office will send a representative to visit the complainant and the local welfare department. A report setting out the facts found in this investigation and the conclusions based upon it is then sent to the state agency for appropriate action.

The citizen's complaint seems to have two values. First, it results in prompt redress for a complainant who has made a good case. Secondly, it is a good source of information for the regional office on local compliance issues. Unfortunately, the regional office seldom effectively utilizes this information for general enforcement purposes. Because of staff limitations, the regional office feels that not every complaint should actuate an administrative review or investigation. Hence, only a large volume of complaints or an extremely well documented complaint suggesting a pattern of maladministration will result in an administrative review. The regional office never reports to the Washington office any issue about which it merely has complaints and has not itself conducted an investigation.

Furthermore, the present complaints procedure seems to have its own Catch 22. Both the Assistant Payments Director and the Regional Commissioner have stated that the reason they are able to handle complaints so efficiently is that they only get a few. If the complaints procedure were to become generally known and utilized, it would collapse in a short time because the regional office has neither the staff nor the desire to act as a reviewing center for local agency practices. The regional office thinks the state department should be doing this on its own. There is at present no systematic method in any state for informing recipients or the general public of the availability of a complaint to HEW. 
Audit-The audit process is not really designed to discover state nonconformity, although it occasionally does so. The auditor, usually from the Federal Audit Agency (a branch of HEW), seeks to determine whether there is an appropriate expenditure of federal funds under the state program, whether the state maintains adequate records, and whether the state is appropriating funds sufficient to cover its share of the welfare expenditures. ${ }^{80}$ The auditor might make an exception on a state's grant, for example, were he to find that people were receiving AFDC benefits for dependents over 18 years of age and not in school, but he could do nothing about the failure to pay benefits to those eligible, except perhaps to report any such discoveries to the regional office of HEW. In fact, according to recent directives from the $\mathrm{Bu}-$ reau of the Budget, the major functions of the federal auditors and of the Department of Management and Fiscal Systems in the regional office seem to be to demonstrate to the states how they can maximize the amount of federal grant funds that they are receiving.

Reports-The Department of Program Planning and Evaluation, despite its name, does not have significant impact on identification of problems of conformity and enforcement. The main function of this department is to help the states submit the thirty or more different statistical reports required by HEW concerning the AFDC system. The reports cover such diverse matters as the number and classification of recipients, fair hearings, methods of dealing with recipient frauds, and statistics on expenditures for assistance to Cuban refugees and U.S. citizens returning from foreign countries. This statistical data flows into the regional office at the rate of some 3,000 reports a year. About all the two staff people in the Department of Program Planning and Evaluation can do with this paper is to compile and file it, and by and large they can do only the latter. Although some of these reports would give information suggesting where compliance problems might arise in various state systems, the Department of PPE's interest in conformity is limited to helping the states get their reports in on time so that their nonreporting will not itself become a conformity issue.

The primary use of this statistical data seems to be to persuade Congress that public assistance funds have been spent legitimately and for

80 The Federal Audit Agency has offices in every state. According to the Virginia office, an audit has not been performed on the state's welfare system in five years because of the recent emphasis on education programs. The Virginia office plans an audit in the near future. In order to accomplish this, however, the office staff, which has no familiarity with the public assistance system, will have to be substantially retrained. 
program development. The Department of Program Planning and Evaluation makes no attempt to put the reports into a form which would specifically aid the compliance and enforcement effort. These reports are, however, passed on, at request, to the Assistance Payment Staff whose director reviews them. She says that a number of clues concerning what she should talk to the state about in her visits come out of the reports.

a. Quality Control. Included in the battery of reports sent to the regional office by each state is the quality control report, which reviews the accuracy of a state's welfare determinations by investigation of a randomly drawn sample of cases. ${ }^{81}$ The quality control system is the embodiment of the basic philosophy of the regional office that the primary responsibility for program evaluation and development lies with the states. HEW has used the requirement that each state conduct periodic quality control reviews as a means for reducing the extent to which the regional office has to directly review a state's welfare practices. Quality control seems to have become, in fact if not in policy, a substitute for full-scale administrative reviews, at least in the critical areas of eligibility and correctness of payments.

In each sample of cases drawn, AFDC cases make up one lot and the adult categories another. The tolerance levels have been set by HEW at three percent for both positive and negative eligibility determinations and at five percent for decisions concerning payments. When a state's quality control report reveals a percentage of error greater than the applicable tolerance level, HEW requires the state agency

81 Quality control is defined as:

[A]n administrative program for determining the extent to which those receiving public assistance are (1) eligible for assistance, and (2) receiving assistance payments in the amount to which they are properly entitled. It is used by the state and federal governments to maintain a continuing and systematic control over the incidence of ineligible recipients and incorrect payments in public assistance caseloads.

As a method of state administration, the quality control system has the purpose of holding the incidence of error below pre-established tolerance limits of errors. It accomplishes this purpose by means of three processes: (1) continuous review of statistically reliable statewide samples of cases; (2) quarterly assembly and analysis of case findings to determine incidence of errors; and (3) when tolerance limits are found to be exceeded, corrective action to bring the level of erroneous cases within the tolerance established.

H. Krueger, Memo. to Superintendents of Public Welfare, Oct. 1, 1970. This description refers to the new quality control system that became operative in October of 1970 . Prior to the fall of 1970 , the states conducted quality control studies once a year and submitted the results to HEW. The regional offices found the results of this procedure to be totally unacceptable. The failure did not lie in the findings of the states but rather in the paucity of state corrective action. 
to indicate in its reports what corrective action it has taken or will take to reduce the rate of errors to a level within the tolerance limit.

A review of quality control reports submitted by Virginia to Region III during the period April 1, 1968-March 31, 1969 indicates that the procedure may not be very effective. In all the reports the incidence of error was above the tolerance levels, and in each case the corrective action listed was either so vague that it was meaningless or should have been required of the state initially in order for it to have a conforming state plan. These errors, of course, become subject to negotiations and questions by the regional office staff in their continuing informal contacts with the state.

Although members of the regional office say that the quality control system provides the best information they have about state operations, the system is seriously deficient in several respects. Most important, the quality control report gives the regional office no real idea about where the problems are. The "intolerable" level of error could be in one or two local welfare offices or it could be randomly spread throughout the state. The report does not indicate whether the errors that appear are part of a general pattern of noncompliance in certain localities or whether they are simply isolated mistakes. This distinction is extremely important in those state systems which are still run through the medium of semi-autonomous local offices. HEW can, of course, require that states further analyze their quality control data to determine whether there are localized problems, but the sample in many localities may be so small that it is statistically meaningless.

b. Central Office Involvement. The compliance manual states that the regional office has ninety days to resolve any difficulty in the implementation of new plan material before reporting the problem as a compliance issue to the central office and proceeding into formal negotiations. ${ }^{82}$ After the ninety-day period has expired, the issue is reported in the region's quarterly compliance report and formal negotiations commence. During this phase, which may last at a maximum of six months, both the regional and central office staff work with the state in an attempt to resolve the issue. When the six-month time period has elapsed, or a determination has been made that further negotiations are of no avail, the Regional Commissioner is supposed to recommend to the Administrator of the Social Rehabilitation Service at the central office that an offer for formal hearing be made to the state.

82 A similar three month period is used when dealing with noncompliance in program operation. 
Once this recommendation has been made, there are no further time restrictions, and, in fact, a great many recommendations simply die in the central office or are referred back to the regional office for further negotiations. It would appear that the central office makes a determination concerning how it will pursue compliance in terms of the type of issue that is involved and also on the basis of other factors, such as the recalcitrance of the state, political pressures, how solid the case is, or whether achieving compliance through a hearing in this case is likely to have a significant impact in achieving compliance elsewhere through less formal means. ${ }^{83}$

It is perhaps for these reasons that the Regional Director of the Assistance Payments Administration in Region III says that the key to achieving compliance is the persistence with which the regional office holds to what it says at the beginning and lets the state know that it is not going to drop the matter. Thus the regional office may stretch out the ninety-day preliminary negotiating phase much longer than ninety days in the hope that within a reasonable time an accommodation can be reached with the state without creating the sort of adversary and often frustrating situation that develops from reporting the state's noncompliance to the central office. However defective this internal administrative process, it resolves some 5,000 potential compliance questions per year in a fashion acceptable to both federal and state agencies.

In conclusion, there is a tendency for federal grantor agencies to stress program development rather than enforcement, to develop a close working liaison with grantees which is likely to be upset by any high visibility conflict, and to deal more effectively with issues of compliance which respond to negotiation than with issues which require large expenditures of effort and political capital. This is an understandable stance, but one which should be counterbalanced by inputs from the persons affected by any noncompliance with federal standards. It is to the provision of a structural system of such inputs through effective complaint mechanisms at both the grantor and grantee levels of administration that this Article's recommendations are directed.

88 Occasionally, the regional office feels seriously undercut by the failure of the central office either to force a compliance hearing based upon the recommendation of the regional office or to issue clarifying regulations which would allow the regional office to deal intelligently with a state which is attempting to comply but does not understand precisely what is required. It is embarrassing to the regional office to have its decisions regarding the acceptability of state compliance reversed by the regulations of the central office. 


\section{Federal Standards Litigation}

The last two or three years have witnessed an unprecedented number of federal suits challenging grant-in-aid programs, on the basis that the operations of such programs do not comply with federal requirements. Litigation concerning compliance with federal grant standards takes essentially two forms: (1) a suit seeking review of a federal grantor agency's funding decision, ${ }^{84}$ or (2) a suit against a grantee claiming that its failure to comply with federal standards has deprived the plaintiff of rights, privileges, or immunities guaranteed by federal law. Suits in the first category raise the normal problems associated with judicial review of federal agency action-jurisdiction, venue, reviewability, and so on-while suits in the second category are normally based on the civil rights acts' provisions. ${ }^{85}$

\section{Litigation as an Indicator of the Compliance Problem}

The level of litigation in the federal courts is a strong indicator that serious compliance problems are being encountered in grant-in-aid programs. In particular, recent litigation has highlighted four areas in which the problem of enforcing federal standards is acute. The first area is that of civil rights, particularly, as stated in Title VI of the

84 This type of litigation has been facilitated by the broadened concepts of standing. Association of Data Processing Serv. Organizations v. Camp, 397 U.S. 150 (1970); Barlow v. Collins, 397 U.S. 159 (1970). It is now generally conceded that the intended beneficiaries of a federal grant-in-aid program who are adversely affected by the operation of the program at the federal, state, or local level have standing to sue the offending officials. E.g., M. M. Cracken Co. v. Portsmouth Redev. \& Housing Authority, 437 F.2d 784 (4th Cir. 1971) (person relocated under urban renewal program). This liberalized concept of standing includes those whose claims are based on their rights as beneficiaries, not of the program itself, but of its general protective obligations. See, e.g., Citizens Comm. for the Hudson Valley v. Volpe, 425 F.2d 97 (2d Cir. 1970); Road Review League v. Boyd, 270 F. Supp. 650 (S.D.N.Y. 1967) (citizens gained standing, not solely by their use of highways, but also by their residential proximity to them); Southern Christian Leadership Conference, Inc. v. Connolly, 331 F. Supp. 940 (E.D. Mich. 1971) (plaintiff civil rights group entitled to standing to challenge a Small Business Administration loan to another party on gronnds, inter alia, that such funds would be used to discriminate against minority owned businesses by the recipient and that the grant would thus be made in violation of 42 U.S.C. $\$ 2000(d)(1970)$ ).

8542 U.S.C. $\$ 1983$ (1970). At least one case has indicated that a private civil action based on federal grant standards might be implied without the aid of 42 U.S.C. $\$ 1983$ (1970). Gomez v. Florida State Employment Serv., 417 F.2d 569 (5th Cir. 1969). Gomez has bred a rash of suits which have been based upon the theory that federally funded employment agencies are violating federal directives by referring migrant workers to jobs providing substandard working conditions. N.Y. Times, Oct. 3, 1971, at 1, col. 4. 
Civil Rights Act of 1964. ${ }^{80}$ In the 1960's HEW cut off federal funds from numerous school districts and hospitals in the South, but a recent Umited States Court of Appeals decision may have undermined HEW's efforts by requiring that $\mathrm{HEW}$ make a finding of discrimination in each program of categorical assistance rather than rest its findings solely on the fact that the recipient discriminated generally in its operations. ${ }^{87}$ HUD has also been involved in Title VI enforcement litigation, as shown by two recent decisions holding local housing authorities in violation of Title VI and the fourteenth amendment because of discrimination in the selection of public housing sites.88 In one recent case, HUD itself was found to have violated Title VI because of its approval of plans which a city had adopted with actual intent to drive out blacks. ${ }^{89}$ Controversy over HUD's civil rights role now centers on the question of the affirmative measures which the Department must take under the Civil Rights Act of 1968 to ensure that its grants do not contribute to segregated housing patterns. ${ }^{90}$

A second area where serious enforcement problems have arisen is in federally assisted state welfare programs. Because of its extreme reluctance to apply the cut-off sanction, ${ }^{91} \mathrm{HEW}$ has failed to take effective action to resolve questions of compliance, even where recipients have claimed clear state violations of federal statutory standards on the eligibility of families for welfare. Welfare recipients have responded with an avalanche of suits against state grantees, alleging deprivations under color of state law of rights guaranteed by the United States Constitution and Title IV of the Social Security Act. ${ }^{22}$

Urban renewal litigation has also highlighted the enforcement problem. Many communities and civic groups have found HUD's enforce-

8642 U.S.C. $\$ 2000$ (d) (1970).

87 Taylor County Bd. of Educ. v. Finch, 414 F.2d 1068 (5th Cir. 1969).

88 Hicks v. Weaver, 302 F. Supp. 619 (E.D. La. 1969); Gautreaux v. Chicago Housing Authority, 296 F. Supp. 907 (N.D. Ill. 1968).

89 Garrett v. City of Hamtrack, 335 F. Supp. 16 (E.D. Mich. 1971).

90 Gautreaux v. Romney, 448 F.2d 731 (7th Cir. 1971).

91 Advisory Commission on Intergovernmental Retations, Statutory and Administrattve Controls Assoctated with Federal Grants for Public Assistance 62-64, 92 (1964).

$92 \mathrm{~A}$ number of these cases have reached the Supreme Court. E.g., Townsend v. Swank, 404 U.S. 282 (1971) (invalidating Illinois' prohibition against receipt of AFDC benefits by college students aged 18-20); Lewis v. Martin, 397 U.S. 552 (1970) (invalidating California's income attribution rule); Rosado v. Wyman, 397 U.S. 397 (1970) (disapproving New York's redetermination of need); King v. Smith, 392 U.S. 309 (1968) (invalidating Alabama's "man in the house" rule). 
ment of public hearing ${ }^{93}$ and relocation ${ }^{94}$ requirements inadequate and have brought suit in federal court to secure the observance of these standards.95 Further litigation is to be expected, particularly after the imposition of important new statutory requirements on urban renewal projects in 1968 and $1969 . .^{\circ 6}$

Persons affected by alleged noncompliance with federal standards contained in the Federal-Aid Highways Acts ${ }^{97}$ have also repaired to the courts to seek relief. While some of the cases involve special claims to relocation assistance, ${ }^{98}$ they are largely suits claiming defects in the planning process required for federally aided highway construction and seeking to enjoin the funding of projects until these defects are cured. ${ }^{98}$

9342 U.S.C. \$1455(d) (1970).

9442 U.S.C. $\$ 1455$ (c) (1970).

95 See, e.g, Norwalk CORE v. Norwalk Redev. Agency, 395 F.2d 920 (2d Cir. 1968); Garrett v. City of Hamtrack, 335 F. Supp. 16 (E.D. Mich. 1971); Home Furniture Co. v. HUD, 324 F. Supp. 1401 (W.D.N.C. 1971); Shannon v. HUD, 305 F. Supp. 205 (E.D. Pa. 1969), rev'd on otber grounds, 436 F.2d 809 (3d Cir. 1970); Western Addition Community Organization v. Weaver, 294 F. Supp. 433 (N.D. Calif. 1968).

96 See 42 U.S.C. $\$ \$ 1455$ (f), (h) (1970). Fixed percentages of housing units in project areas redeveloped for predominantly residential uses must be for moderate and low income persons. Low and moderate income units must be provided "at least equal in number" to the number of such units that existed prior to demolition if the vacancy rate in the locality is less than five per cent.

9723 U.S.C. $\$ \$ 101$ et seq. (1970).

98 E.g., Triangle Improvement Council v. Ritchie, 449 F.2d 423 (4th Cir. 1970); Hanley v. Volpe, 322 F. Supp. 1306 (E.D. Wis. 1969).

99 Because of the nature of the federal standards, the complaint usually takes the form of allegations that the state highway department has not touched all the bases necessary for grant approval, for example, the holding of public hearings. See D.C. Federation v. Volpe, 434 F.2d 436 (D.C. Cir. 1971); Lukowski v. Volpe, No. 20634 (D. Md. filed April 7, 1969). Occasionally it may be possible to allege that the facts do not warrant a finding made by the Secretary of the Department of Transportation or that the Secretary has not made a finding specifically required of him. Examples can be found in Citizens to Preserve Overton Park, Inc. v. Volpe, 401 U.S. 402 (1971); Named Individual Members of the San Antonio Conservation Soc'y v. Texas Higlwway Dep't, 446 F.2d 1013 (5th Cir. 1971); D. C. Federation v. Volpe, 434 F.2d 436 (D.C. Cir. 1970); Brooks v. Volpe, 319 F. Supp. 90 (W.D. Wash. 1970); Pennsylvania Environmental Council, Inc. v. Bartlett, 315 F. Supp. 238 (M.D. Pa. 1970). In particular, Citizens to Preserve Overton Park, Inc. has been a major factor in introducing an increased judicial involvement in the grant process. In that case the Supreme Court found that the Secretary of Transportation's highway funding decision was reviewable and directed the district court to determine: whether he acted within the scope of his authority, whether his decision was arbitrary, capricious, or an abuse of discretion, and whether applicable procedural requirements were observed. 401 U.S. at 415-16. 


\section{The Efficacy of Litigation as a Compliance Technique}

Remedies-Although the remedies aspect of the law of federal grants has been developing rapidly, it is still in its infancy. The question of remedies has been particularly difficult in the welfare area, where a cut-off of federal funds, the basic remedy of both courts and agencies, tends to fall especially hard on the intended beneficiaries. In Rosado v. Wyman, ${ }^{100}$ for example, the Supreme Court declared New York's method of determining need inconsistent with federal requirements, but then remanded the case to the district court to fix a date which would afford the state an opportunity to revise its program. If New York did not do so by the determined date, the district court was to enter an order restraining the further use of federal moneys. ${ }^{101}$ Justice Douglas, in a concurring opinion, recognized the danger in such a remedy: "That a State may choose to refuse to comply with the federal requirements at the cost of losing federal funds is, of course, a risk that any welfare plaintiff takes." 102 Justice Douglas did not mention that the plaintiff takes that risk not only for himself but for all New York welfare recipients. The Court seems to have avoided such risks in some cases by simply declaring the state statute or regulation invalid. ${ }^{103}$ This is feasible, and perhaps sound, where the "invahd" state regulation is not necessary for the program's administration and can be held entirely void without any need for its being replaced. However, there would appear to be no bar to a state's continued application of the offending provision were the state to decline further federal funding..$^{104}$

Another major limitation on the judicial relief available, particularly in urban renewal and highway programs, is that the plaintiffs may not seek or obtain judicial review until after considerable costs have been expended on the project. ${ }^{105}$ In Norwalk CORE v. Norrwalk Redevelopment Agency, ${ }^{106}$ for example, the project had been completed by the time the court recognized the plaintiff's standing to sue. Even when

100397 U.S. 397 (1970).

101 Id. at $421-22$.

$102 \mathrm{Id}$. at 427 .

103 E.g., King v. Smith, 392 U.S. 309 (1968) (the "man in the house" rule).

104 But see Judge Thornberry's "federalization" of the state highway department in Named Individual Members of the San Antonio Conservation Soc'y v. Texas Highway

Dep't, 446 F.2d 1013 (5th Cir. 1971).

105 Road Review League v. Boyd, 270 F. Supp. 650 (SD.N.Y. 1967).

106395 F.2d 920 (2d Cir. 1968); see McGee, Urban Renewal in the Crucible of Judicial Review, 56 VA. L. REv. 826, 866-67 (1970). 
the project is not completed, the sunk costs may deter courts from granting sweeping relief. This timing problem has been mitigated by regulations allowing challenges to administrative decisions before actual construction begins ${ }^{107}$ and by judicial decisions allowing early review. ${ }^{108}$ As stated by former Justice Black, .

[I]t is simply not realistic to consider the construction of [an] expressway "section by section" .... Once construction is begun and heavy investment made on the two end segments, the available options for routing the middle segment are severely limited. ${ }^{109}$

Institutional Considerations-Even with the maturing of the remedies aspect of the law of federal grants, judicial review is not likely to provide effective enforcement of standards. Judicial review is characteristically a slow and expensive process. In areas such as public assistance, only the major test case can be mounted, because judicial relief for individuals costs more than the benefits derived. The problem is solved only partially by the thin ranks of free counsel.

The method of judicial review, particularly of a federal grantor agency's determination, poses its own difficulties. For example, uuder the Administrative Procedure Act courts must decide whether the Secretary of Transportation, in making certain required findings before funding highways, ${ }^{110}$ has acted within his scope of authority and in a manner not arbitrary, capricious, or constituting an abuse of his discretion. ${ }^{111}$ According to Citizens to Preserve Overton Park, Inc. $v$. $V o l p e,{ }^{112}$ the former inquiry consists of a look into the nature of the administrator's authority and discretion, including those standards and criteria which govern his decisions, and a determination of whether,

107 See, e.g., workable program requirement under an urban renewal program, notes $42 \& 43$ supra and accompanying text.

108 See, e.g., Citizens' Comm. v. Volpe, 425 F.2d 97 (2d Cir. 1970); Hanley v. Volpe, 305 F. Supp. 977 (E.D. Wis. 1969); Road Review League v. Boyd, 270 F. Supp. 650 (S.D.N.Y. 1967).

109 Named Individual Members of the San Antonio Conservation Soc'y v. Texas Highway Dep't, 400 U.S. 968, 970-71 (1970) (dissenting from denial of certiorari). Black's reasoning was subsequently adopted by the circuit court, 446 F.2d 1013 (5th Cir. 1971).

110 E.g., 23 U.S.C. $\$ 109$ (a) (1970) (the proposed facility must adequately meet the existing and probable future traffic needs in a manner conducive to safety, durability, and economy of maintenance); 23 U.S.C. $\$ 138$ (1970) (parkland can only be used for highway construction if the Secretary finds that there is no feasible and prudent alternative).

1115 U.S.C. $\$ 706(2)$ (1967) (Supp. 1972).

“112 401 U.S. 402, 415-16 (1971). 
given the facts that he knew or should have known, his decision can reasonably be said to be within that range. The latter inquiry consists of a determination of whether the Secretary's decision was based upon a consideration of all the relevant factors and whether the decision made was unreasonable or a clear error of judgment.

This review of grant decisions is costly to litigants and expensive in terms of judicial resources. With a few exceptions, ${ }^{113}$ present highway laws do not require formal findings of fact and law. A reviewing court must make a complex examination of all the factual inputs into the administrative process. Furthermore, since the "bare record may not disclose the factors that were considered or the Secretary's construction of the evidence," 114 actual testimony of the administrative decision-makers may be required. ${ }^{115}$ This is bnrdensome to courts and administrators alike and makes judicial review an awkward compliance weapon. Such a detailed judicial examination of the adminstrative process also means that the complainant is not likely to be successful often. A court reviewing broad requirements on a standard of arbitrariness or capriciousness and relying on testimonial proof concerning mental operations cannot be expected to upset administrative judgments except in the most egregious situations.

Indeed, should the statutory standard be less stringent than the one involved in Overton Park, judicial review may be largely perfunctory. In Western Addition Community Organization v. Weaver, ${ }^{116}$ HUD had never made the required determination that satisfactory arrangements had been made for relocation of displacees. The court enjoined the Secretary of HUD from honoring future requisitions from the local agency for federal funds until such a plan had been approved. The Secretary subsequently found the local agency's relocation plan and assurances satisfactory to him, and the court dissolved the injunction. The court viewed its role on reviewing the Secretary's determination narrowly:

113 E.g., 42 U.S.C. $\$ 4332$ (c) (1970) (Supp. 1972) (provision of the National Environmental Policy Act requiring a detailed study of probable environmental effects before approval of major federal projects); Department of Transportation Order No. 5610.1 (Oct. 7, 1970) requires the Secretary to make formal findings when he approves the use of parklands for highway construction.

114 Citizens to Preserve Overton Park, Inc. จ. Volpe, 401 U.S. 402, 420 (1971).

115 See, e.g., D.C. Federation v. Volpe, 316 F. Supp. 754 (D.D.C. 1970), rev'd on other grounds, 434 F.2d 436 (D.C. Cir. 1971), cert. denied 92 Sup. Ct. 1290 (1972).

116294 F. Supp. 433 (N.D. Cal. 1968). 
[T] he judicial function is narrowly limited to ascertaining whether the Secretary has made the determination required of him by law, and, if so, whether he has acted in apparent good faith, reasonably rather than arbitrarily and with some factual basis for his decision. If so, judicial review can go no further. ${ }^{117}$

Moreover, in areas such as welfare litigation, the nature of the proceeding may require at least preliminary examination by a three judge court and expedited appeal to the Supreme Court. ${ }^{118}$ Scarce judicial resources are thus being consumed in some compliance litigation at three times their normal rate. Since the pressure from welfare compliance litigation is great, it is conceivable that the federal court pipeline for determination of welfare issues will begin to be closed off on jurisdictional grounds. Because $\$ 10,000$ can seldom be seriously alleged as the amount in controversy in a welfare claim (these are not the type of class action claims that may be aggregated), the welfare claimant or claimants must allege a colorable constitutional issue in order to give a federal court jurisdiction. ${ }^{119}$ These constitutional issues largely involve equal protection, and since the Supreme Court's retrenchment from an expanded review of state social welfare legislation in Dandridge $v$. Williams, ${ }^{120}$ it is conceivable that federal district courts will increasingly decline jurisdiction on grounds of failure to allege a substantial federal question.

Nor is it likely that compliance litigation can effectively be shifted to state courts. State judiciaries have been considerably less hospitable than federal courts to suits against grantees based on federal grant standards. Illustrative is the highway grants field, where the approach of the state courts has been that federal standards are conditions on funding and relevant only to a grant decision by FHWA. ${ }^{121}$ Occasionally state statutes will direct that state officials comply with federal highway standards, ${ }^{122}$ but even then the court may take the FHWA

117 Unreported decision of March 5, 1969, see $A B A$ National Institute on Federal Urban Grants, 22 Ad. L. Rev. 113, 268 (1970).

11828 U.S.C. $\$ 2281$ (1970). The reason is that the welfare claimant almost always seeks to enjoin local or state agency implementation of state law on grounds of a violation of the claimant's federal civil rights.

11928 U.S.C. \$1343(3) (1970).

120397 U.S. 471 (1970).

121 See, e.g., Morningside-Lenox Park Ass'n v. State Highway Dep't, 224 Ga. 344, 161 S.E.2d 859 (1968); Futch v. Greer, 353 S.W2d 896 (Tex. Ct. Civ. App. 1962); Linnecke v. Department of Highways, 76 Nev. 26, 348 P.2d 235 (1960); Piekarski v. Smith, 38 Del. Ch. 402, 153 A.2d 587 (1959).

122 E.g., N.Y. Hrghway Law $\$ 85$ (McKinney 1962). 
approval of the project as conclusive evidence of the satisfaction of these requirements. ${ }^{123}$

In conclusion, while recognizing the tremendous impact that litigation may sometimes have in furthering comphance with federal standards, ${ }^{124}$ the accelerating incidence of litigation concerning federal grant programs is probably more symptomatic of disease than evidence of the application of effective therapy. The proposals which follow are not a panacea for the ills of the various grant-in-aid programs. They are, however, designed to introduce a modicum of order and responsiveness into the process of disposing of claims alleging a failure to comply with standards attached to federal grants-in-aid.

\section{RECOMMENDATION}

\section{A. The Federal Administrative Complaint Procedure ${ }^{125}$}

The federal grantor agency should have an administrative procedure for the receipt and impartial disposition of complaints by persons affected by the grant-in-aid program that a plan, project application, or other data submitted by a grant applicant or grantee as a basis for federal funding does not meet one or more federal standards. This procedure should afford the complainant an opportunity to submit to the grantor agency for its consideration data and argument in support of the complaint and should afford the grant applicant or grantee involved a fair opportunity to respond to the complaint. If the agency determines that the complaint is not valid, it should notify the complainant of its determination and should state in writing the reason for its decision. If the agency determines that the complaint is valid, it should notify both the complainant and the grant applicant or grantee of its determination and should state in writing the reason for its decision. If the agency exercises discretion not to make a determination on one or more issues raised by a complaint, it should so notify the complainant in writing. The agency should dispose of all complaints within a prescribed period of time.

The complaint procedure administered by the federal grantor agency should also provide for the receipt and impartial disposition of com-

123 See Town of Clearmont v. State Highway Comm'n, 357 P.2d 470 (Wyo. 1960).

124 See, e.g., Barrett, The Role of the Courts in Welfare Reform, 1970 Duke L.J. 1; National Center for Social Statistics, Trendos In AFDC in 1965-1970 and Selected Annual Periods, Report H-4 (1970).

125 The Administrative Conference has slightly altered the language of Part A. Administrative Conference of the United States, Recommendation 31: Enforczment of Standards in Federat Grant-in-Aid Programs (Adopted, December, 1971). 
plaints that a grantee has in its administration of the funded program failed to comply with one or more federal standards. It is anticipated that many grantor agencies will find it necessary to limit their consideration of such complaints to situations in which the complainant raises issues which affect a substantial number of persons or which are particularly important to the effectuation of federal policy and will, therefore, dispose of most individual complaints concerning grantee administration by referring the complainant to such complaint procedures as are required to be established by the grantee. The grantor agency should by regulation define the classes of cases that it will consider sufficiently substantial to warrant processing through the federal complaint procedure and those classes of cases wherein complainants will be required to pursue a remedy through available complaint procedures administered by the grantee.

The purpose of Part $A$ is to strengthen the role of federal grantor agencies in enforcing federal standards in grant-in-aid programs. It proposes that federal agencies respond to the problems of enforcement by developing administrative procedures for handling complaints that a grantee has not complied with federal standards. The initiation by federal agencies of formal complaint procedures, or the strengthening of existing procedures, should lead to a broader acceptance within the federal agencies of their responsibility to enforce federal standards. In practice, complaint procedures should also operate to provide federal agencies with more complete information on compliance problems and to shift from the courts back to the federal agencies the primary role in resolving questions of compliance with federal standards.

Federal agencies should, of course, seek to achieve increased compliance with federal standards through any other means that prove effective. They may conduct educational programs to inform grantees of their obligations and may provide technical advice and services to aid grantees in complying with federal standards. These techniques recognize that a grantee's noncompliance may be due to ignorance or to staff limitations rather than to any conscious disregard of federal standards. The federal grantor agency might also clarify its interpretation of applicable federal standards and even develop models for grantee administration that would assist grantees in conforming with federal standards in their program operations. Other techniques for improving compliance with federal standards include more intensive or frequent administrative reviews of grantee operations and an audit system designed to detect grantee expenditures that violate federal standards. 
Part A singles out the administrative complaint procedure, because that technique recognizes that the ultimate beneficiaries of grant-in-aid programs have a significant interest in the grantee's compliance with federal standards. In recent years there have been widespread efforts by individual citizens and public interest groups affected by grant programs to hold program officials accountable for their actions. These efforts often result in law suits but may also take the form of concerned citizens' meetings, petitions, and campaigns in the mass media. A federal administrative complaint procedure would involve these private interests in the compliance and enforcement process of the federal agency, which should in turn lead to an improved record in enforcing federal standards. In addition, an effective complaint mechanism should convince the beneficiaries of the grant-in-aid program that the grantor agency is responsive to their interests and thus restore their confidence in the grant program.

Encouragement to individuals and public interest groups to police grant programs may cause some discomfort to administrators who find the interference troublesome. Organizations of welfare recipients, conservationists, neighborhood residents, public housing tenants, and other persons affected by grant programs may demand a lot, and their views may conflict sharply with those of program officials of the federal agency or of the grantee. These pressure groups, however, have interests of the same legitimacy as more established and therefore more familiar group claimants, such as professional and trade associations, labor umions, veterans organizations, and the Chamber of Commerce. Their tactics may sometimes be abrasive, but their presence is important for informed decision-making concerning the allocation of federal funds. Too often in the past they have been left out of the administrative process. ${ }^{126}$

\section{Scope of Application}

\section{Complaints Directed at Grantee Submissions-Part A covers com-}

126 Reforms in the system of federal grants-in-aid, such as the consolidation of grant programs and the institution of block grants, have benefited state and local grantees by strengthening their role in the grant process without any corresponding recognition of the role of the ultimate beneficiaries of the system. Other examples of reform include the areawide planning requirements of $\$ 204$ of the Demonstration Cities and Metropolitan Development Act of 1966, 42 U.S.C. $\$ 3354$ (1970); the prior consultation on new federal agency regulations and standards to which the heads of state and local governments are entitled under Bureau of the Budget Circular A-85 (June 28, 1967); and the greater reliance on state and local government that is a hallmark of the "new federalism." 
plaints that a plan, project application or other data submitted as a basis for federal funding does not meet federal standards. The words "plan, project application or other data" are intended to cover at least six types of submissions: (1) state plans which must be approved by the federal agency to qualify for a formula grant, (2) state, regional, or local plans which must be approved by the federal agency before a project grant will be awarded, (3) amendments to both these types of plans, (4) project applications for individual project grants, (5) amendments to project applications, and (6) reports and factual data which are submitted with a plan or project application or at a later stage to demonstrate that a grantee has met specific federal standards. In all cases the word "submission" should be liberally construed to cover the operative provisions of a grantee's plan or application and should not be restricted to documents that are physically transferred from the grantee to the grantor. For instance, a state plan submitted to HEW to qualify for a formula grant may summarize or only refer to the state's operative statutes and regulations and need not contain their actual texts. The statutes and regulations are nevertheless part of the state plan, and a complainant should be able to challenge their conformity with federal standards.

The majority of complaints processed under this aspect of the federal complaint procedure should be complaints directed at pending plans, applications, or amendments thereto that have been submitted to the federal agency but not yet acted upon or approved by it. Ideally, as many complaints as possible should be resolved at this stage, before the agency has made a funding decision by approving the submission. For example, potential displacees should be able to complain that a relocation plan accompanying an application for an urban renewal grant does not comply with federal standards. ${ }^{127}$ Such complaints would raise issues that are basic to the effectuation of important federal pohcies, and grantor agencies should, if possible, seek to resolve them prior to plan approval.

The complaint mechanism with respect to grantee submissions is intended to function in two additional situations. First, it covers complaints that the federal agency has improperly approved plans or applications that do not in fact conform to federal standards or that plans

127 The administrative complaint procedure would also allow complaints by welfare recipients who claim that a new state statute or regulation on eligibility for assistance or income disregard violates federal standards, or by conservation groups who claim that a state highway project does not conform to federal environmental or planning requirements. 
or applications submitted and approved in the past are no longer valid because they have not been brought into conformity with newly imposed federal standards. Both aspects of this problem have recently arisen in the area of social assistance grants to the states where HEW is now questioning the conformity to federal standards of state plan material submitted and approved years ago. Although the states involved have continued to receive federal funds on a regular basis, they have either never submitted adequate plan material to HEW or have not conformed their plan material to new federal requirements. In these situations federal agencies should entertain complaints that plan material or applications no longer conform to federal standards. Of course, a federal agency need not continually redetermine issues of compliance and may dispose of subsequent complaints by informing the complainant that a particular issue has already been resolved by the agency.

Secondly, the complaint procedure in Part A encompasses situations where the federal agency must make a finding that federal requirements have been satisfied before it releases federal funds to the grantee or before it approves the initiation or continuation of a federally assisted program or project. Thus, where a state highway plan calls for the taking of parkland, the federal agency should entertain complaints under section 138 of the Federal-Aid Highways Act ${ }^{128}$ that a feasible and prudent alternative route does exist or that all possible planning has not been done. This function of the complaint mechanism overlaps with the primary function of resolving complaints at the application stage. Often the grantee will be required to include in its application the factual data it beheves will support a determination that federal standards have been satisfied. The federal agency, however, may feel compelled to determine, not only at the application stage but also at a later time when the project is fully planned or even partially executed, whether the data supports a finding of compliance with federal standards. Complete data often is not available at the application stage, and Congress has sometimes required that the federal agency make the requisite finding in mid-project. For example, in urban renewal project grants HUD must be satisfied at a reasonable time prior to the actual displacement of individuals and families that adequate relocation housing is available for them. ${ }^{120}$ Where the agency makes the crucial determination resulting in the continued flow of federal funds at a

12823 U.S.C. \$ 138 (1970).

12942 U.S.C. $\$ 1455$ (c) (2) (1970). 
point in time later than the application stage, complainants should be able to take advantage of the proposed complaint procedure at that time.

Complaints Directed at Grantee Operations-The second paragraph of Part A covers complaints that a grantee has failed to comply with one or more federal standards in the administration of a federally aided program. Since compliance in practice is the compliance that really counts, the federal agency should not limit its complaint procedure to issues of paper compliance. Rather, it should also assume responsibility for handling complaints that a grantee is not complying in practice with federal standards, including those standards provided in Part B concerning a grantee's complaint procedures.

The provision concerning operational complaints is narrow, covering only those complaints that raise issues which affect a substantial number of persons or which are particularly important to the effectuation of federal policy. Compliance issues which affect a substantial number of persons include a state or local welfare agency's failure to process promptly applications for assistance, ${ }^{130}$ the failure of a lospital aided under the Hill-Burton Act to accept charity cases, and a public housing authority's insertion of improper provisions into its tenants' leases. Even when the challenged action of the grantee affects only one person, the federal policy at stake may sometimes be important enough to channel complaints through federal complaint procedures. This is particularly likely to occur where there is some danger that grantees will be hostile or indifferent to the federal policy. The most important example is the federal policy of nondiscrimination. All of the regulations implementing Title VI of the Civil Rights Act of $1964^{131}$ require federal agencies to process directly individual complaints of discrimination in federally assisted programs, and such complaints would clearly fall within the proposed procedure. The federal agency should by regulation define those classes of cases in which it would make available the grantor complaint procedure to process individual complaints concerning grantee practices.

The second paragraph of part A recognizes that individual grievances may in many cases be better handled through the grantee's complaint procedure recommended in Part B, below. The grantee's complaint mechanisms are likely to be more conveniently located and accessible to the complainant, and the grantee is likely to have more ready access to 
the facts. Fair complaint procedures at the grantee level should satisfactorily resolve the great majority of individual complaints. Furthermore, to require the federal agency to handle individual complaints would impose a significant burden on the agency, a burden which should be imposed only for good reasons. ${ }^{132}$

Agencies may, of course, disagree about when individual complaints should be heard at the federal level. HUD has determined under the Uniform Relocation Assistance and Land Acquisitions Policies Act of $1970^{133}$ that a claimant dissatisfied with a grantee's determination of his eligibility for relocation benefits or the amount thereof may appeal to the federal agent, ${ }^{134}$ while DOT does not process complaints concerning individual relocation benefits. ${ }^{135}$ Careful study is needed to determine which approach is better in the context of particular programs, but as a general matter it does not appear desirable for the federal agency to handle individual complaints. These complainants should pursue their remedies under the grantee's complaint procedures and, if not satisfied with the result, should then be able to take their individual grievances to court without further delay. An additional processing of their complaints through a federal administrative complaint procedure would be duplicative and wasteful from the point of view both of the federal agency and of the complainant where no pattern or practice of non-comphance is involved.

\section{Structure of the Federal Complaint Procedure}

Part A permits federal agencies to retain great flexibility in structuring the proposed administrative complaint procedure. Implementation requires, however, that an agency make public a procedure to receive and impartially dispose of complaints that a grantee's submissions or operations violate federal standards.

The federal agency should delegate the responsibility for handling complaints to designated officials in the regional or area offices of the agency. These officials should have the responsibility for investigating complaints to determine their validity and for disposing of all com-

132 For example, HEW should not be required to handle the complaint of an individual welfare recipient who is upset about the termination or reduction of his benefits.

13342 U.S.C. $\$ \$ 601$ et seq. (1970).

13424 C.F.R. $\$ 42.190$ (1971).

13549 C.F.R. $\$ 25.21$ (1971). On the other hand, HUD's procedure does not contemplate an appeal to the grantor on the question of whether an individual has been relocated into substandard housing, a question of considerable importance to the beneficiary of relocation assistance. 
plaints in an appropriate fashion. Their identities should be publicized and prospective complainants directed to them. The decisions of these officials may, if the agency chooses, be subject to further administrative review at a higher level within the agency.

Unlike other hearing procedures, independent hearing officers are not desirable for the federal complaints process. In most cases it will be desirable to closely integrate the enforcement process and program administration. An important function of a complaint mechanism, one which even a minor complaint can perform, is to supply the federal agency with information and notice as to compliance questions. Program officials who handle complaints are able to utilize the information which they acquire in this role in deciding whether to conduct administrative reviews and in making informal efforts to educate grantee personnel about federal requirements and to persuade them to comply. A well informed program official may in this fashion bring about a high degree of compliance with federal standards without imposing any formal sanctions. Furthermore, the formal handling of complaints by program officials should focus their attention on compliance questions and make them more enforcement oriented. Also, it would be difficult to attract high calibre personnel for a purely enforcement section of an agency, since the political flack that would almost certainly be encountered and the segregation from the mainstream of the agency might inhibit their career advancement. Finally, it may well be that wholly "independent" administrative decisions on conformity questions are not possible where there is a question of conflict between state and federal governments. Advancement of long term federal and beneficiary interests is more likely to be achieved in many instances through coordinated enforcement and program administration, subtlety, and political acumen than through "judicialization" of the complaints process.

Part A leaves the nature of the hearing afforded to the complainant largely to the determination of the federal agency. The recommendation does provide, however, as a minimum requirement for a fair hearing, that the complaint procedure afford the complainant an opportunity to submit data and argument in support of the complaint. Written submissions will be an appropriate basis for decision in most cases. In some instances, however, as where the complainant is not represented by an attorney and cannot be expected to ascertain independently the precise legal basis for his complaint, the complainant should also be able to present his complaint orally to an agency. official. Where appro- 
priate, the official designated to handle complaints should seek to resolve them through informal negotiation and conferences between the complainant and representatives of the grantee. While due process does not require that the federal agency afford complaining beneficiaries a trial-type hearing, ${ }^{136}$ there are some cases where formality may be desirable. The agency should therefore have available a formal procedure for a full hearing on a complaint at which the complainant and others similarly situated, as well as representatives of the grantee, may present testimony and oral argnment. For example, complaints directed at grantee practices affecting a substantial number of persons, such as the relocation of displacees or eviction of tenants, may raise substantial contested issues of fact. Ventilating these factual issues at a public hearing may serve a number of useful purposes. First, it should help the federal agency determine what the real facts are. Second, the publicity that accompanies the disposition of the complaint may serve as an effective sanction for achieving compliance with federal standards by the grantee. If a public hearing discloses widespread violations of federal standards, a grantee is under considerable pressure to rectify the situation. ${ }^{137}$ Third, a public hearing slould convince the complainants that the federal agency is responsive to their needs and may even convince them that the grantee's noncompliance is not as widespread as they originally thought. Finally, if an agency holds a full hearing, a reviewing court should more readily defer to any findings of fact made by the agency.

\section{Agency Discretion not to Resolve Complaints}

Part A permits a federal agency to exercise discretion not to determine one or more issues raised by a complaint. It is important that the agency in such cases notify the complainant within a prescribed period of time of its decision not to act. This should allow the complainant to pursue any judicial remedies available free of the encumbrance of

136 E.g., Kendler v. Wirtz, 388 F.2d 381 (3rd Cir. 1968) (railway workers affected by a mass transit grant); Hahn v. Gottlieb, 430 F.2d 1243 (1st Cir. 1970) (tenants of a "below market interest rate" project affected by a rent increase); Powelton Civic Home Owners Ass'n v. HUD, 284 F. Supp. 809 (E.D. Pa. 1968) (residents challenging the area's urban renewal eligibility). While the nature of the factual and legal issues in dispute determines the type of hearing which is required, courts are reluctant to impose "trial-type" procedures where informal procedures serve as well. See First National Bank v. Saxon, 352 F.2d 267, 273-76 (4th Cir. 1965) (Sobeloff, J, dissenting). If a formal liearing is required, federal agencies should follow that procedure.

187 See p. 680 infra. 
doctrines such as exhaustion of administrative remedies and primary jurisdiction.

For two major reasons it seems desirable that federal agencies retain some discretion as to when they formally raise compliance issues in the public forum. First, the federal agency is not merely a neutral arbiter in compliance proceedings but has other independent enforcement responsibilities. It should, therefore, not be forced by the mere filing of a complaint either to rely on the possibly inadequate submissions of the parties or to allocate agency resources to the development of facts and policy in an area that it does not consider as significant to the accomplishment of federal objectives as other compliance issues to which the same resources might be devoted. Since most agencies could not thoroughly investigate every alleged compliance issue without outrageous expense, some capacity for assignment of priorities is essential. Discretion not to decide a complaint is one means of providing such capacity. ${ }^{138}$

Second, the agency should be in a position to decide whether compliance can be better ensured in a particular situation by low visibility conflict or negotiation rather than by surfacing issues in a public hearing. Particularly where state or local governments are involved, the cooperative approach may often achieve a higher degree of overall compliance with federal standards than the public confrontation that follows a finding of nonconformity. For example, stringent enforcement of federal standards by HEW would rapidly become politically unacceptable because of that program's particular characteristics. First, it is not a popular program. Second, the states do not admit that Congress has any particular wisdom in dealing with public assistance recipients or in structuring public assistance programs. Third, there is a large investment of state money and occasionally a substantial investment of local funds in the program. Fourth, the conflicts between state operation and federal standards which may surface as a result of the proposed complaint process will require changes in state plans that, at least in some instances, can only be made by state legislatures. Fifth, the funds for an increased enforcement effort, including provision of hearing personnel, must come from Congress. These five factors taken together are almost certain to produce a highly charged political

138 This proposal is in accord with the present law which recognizes the standing of affected persons to intervene in a conformity hearing once the agency has raised an issue of noncompliance. On the other hand, it does not recognize their standing to trigger a conformity proceeding by raising new compliance issues. National Welfare Rights Organization v. Finch, 429 F.2d 725 (D.C. Cir. 1970). 
atmosphere around hearings held on complaints concerning a state system. HEW may find it desirable to seek solution to many of its conformity problems by means other than the conflict mechanism. While it might be argued that the level of political conflict will diminish as the complaints process becomes part of the welfare scene, most observers of the politics of welfare do not believe it. ${ }^{139}$

An agency's decision not to resolve issues raised in a complaint does not mean the agency should bury those issues. The complaint procedure has supplied the agency with information on a potential problem, and the agency should use that information in its informal contacts with the grantee. In those informal contacts, the federal agency should communicate any doubts about the grantee's compliance and discuss possible modifications or adjustments in the grantee's plan or application that would resolve the doubts while still permitting the grantee to proceed with its program.

There are arguments against recognizing federal agency discretion not to resolve complaints. Recognition of this discretion may reduce the role of the federal agency in resolving compliance questions and limit the participation of affected persons in the agency's compliance and enforcement process; it is thus in some sense inconsistent with the main thrust of the recommendation. The federal grant-in-aid system, however, has many ambiguities. It depends for its ultimate success on the effectiveness of the federal agency in achieving compliance with federal policy through the use of all the techniques at its disposal. A complaint procedure should improve the effectiveness of the grant system, but at the same time it should avoid abstract judgments concerning the use of particular compliance techmiques which might interfere with the federal agency's primary responsibility for developing and implementing an effective enforcement program.

\section{Present Agency Practices}

The implementation of Part $\mathrm{A}$ will require some affirmative action by all federal grantor agencies covered by the recommendation. The recommendation contemplates a publicized complaint procedure which,

139 See, e.g., G. Steiner, Social Insecurity: The Politics of Welfare (1967). One observer of the development of the AFDC program concludes that the congressional intent must be for the federal grant policies to influence state actions but not control them. This is the only way to reconcile the fact that federal standards are precisely and explicitly provided and yet ineffectually enforced. M. Derthick, The INFLuence or Federal Grants: Public Assistance in Massachusetrs (1970). 
as part of the federal agency's enforcement machinery, provides a forum for resolving issues of compliance. Existing complaint procedures do not meet these criteria. While agencies do respond to complaints and often make substantial efforts to investigate the matters and to help the complainants, the process is too often haphazard. Prospective complainants do not know to whom in the agency they should direct their complaints or who has responsibility for resolving them. And when individual complaints are fully processed to the satisfaction of the complainant, the amount of agency time expended in the effort may be greatly disproportionate to the benefit secured. For example, research at the HUD regional offices in Philadelphia and New York revealed that an inordinate amount of time was spent handling the relatively small number of individual complaints that came to the attention of the field staff. The arrival of more complainants would have swamped the process. More serious complaints challenging whole projects were never really resolved but instead were shunted to the courts.

$H U D-H U D$ receives a considerable number of complaints that workable programs filed by local governmental units for certification by HUD and applications for loan and grant contracts for urban renewal projects do not conform to federal standards, particularly with respect to the provision of low-income housing and the relocation of displaced persons. Often these complaints are drafted by lawyers and resemble a plaintiff's complaint in a law suit. They are entitled administrative complaints, and lengthy allegations of fact are often supported by documentary material. The impetus for preparing these administrative complaints evidently came from the decision in Powelton Civic Home Owners Association v. HUD. ${ }^{140}$ Powelton held that the residents of an urban renewal area had a due process right to submit to HUD for consideration documentary evidence and written argument challenging the eligibility of an urban renewal project in Philadelphia for federal funding. One senses, however, that the lawyers' purpose in filing administrative complaints with HUD is not so much to convince HUD of the merits of their clients' case as to avoid the defense in a subsequent judicial action that their clients did not exhaust their administrative remedies. The Department of Justice raises this defense routinely, even though there are presently no formal remedies available to exhaust.

HUD's reaction to these complaints is positive. It reads and considers any relevant written material received and responds in writing to all complaints. Normally the regional offices handle this task, but the

140284 F. Supp. 809 (E.D. Pa. 1968). 
Washington office may become involved if the complaint is troublesome or was directed to the Washington office initially. Often the General Counsel's staff responds to complaints; program officials handle complaints even though they are closely involved in planning and administering the grants which generated the complaints. ${ }^{141}$

HUD's present procedures lack the designation of specific officials to receive complaints and to resolve, in a reasoned fashion, issues of compliance. The adoption by HUD of a more formal structure to handle complaints would have at least four beneficial results: (1) it would force HUD to clarify its own thinking on compliance questions; (2) in cases where HUD found noncompliance, it would pressure state and local governments to revise their plans and applications to conform to federal standards; (3) in cases where HUD found compliance, it would often forestall litigation, either because the complainant was satisfied with the explanation or was convinced that it was futile to pursue the matter further; and (4) if the complainant nevertheless took the matter to court, the court would have the benefit of HUD's views and expertise on the compliance issue and might accord them considerable weight. ${ }^{142}$

FHWA-Citizen complaints under the federal-aid highway program are generally processed through conferences among the division engineer (or his staff), the complainant, and state highway department personnel. There is no formal process for making a complaint except at public hearings. ${ }^{143}$

The FHWA at one time proposed to structure the complaints process but was met with strong resistance by state highway officials. The proposal provided for an appeal to the FHWA from the Division Engineer's approval of state highway department location and design decisions after the required public hearings. Within certain time limits any "interested person" was to be allowed to appeal, which would stay the release of funds for the project until a determination was made on the complaint. State officials thought this process would take away

141 On one occasion a well documented complaint led to a HUD field investigation that resulted in the rejection of the application of the Westside Urban Renewal Project in Pulaski, Tenn., Berger and Cogen, Responsive Urban Renewal: The Neighborbood Shapes the Plan, 1 URBan L. Annual 75, 106-17 (1968).

142 State and local governments applying for grants should not be prejudiced by a complaint procedure. They have always been given ready access to agency officials. The recommendation does not affect any right that they may have' to a hearing or review of the decision to deny or withhold federal funds.

143 The Division Engineer in Virginia, however, reports that his office deals with three or four complaints per week which may arrive from the office of the Secretary of DOT, from a local congressman, or even from the office of the President. 
state prerogatives, allow any troublemaker to delay a project at least temporarily and destroy the assurance to the state highway departments that federal funds would be available at the various stages of the project when required. Taking account of these comments, the FHWA withdrew the proposal for further study. ${ }^{144}$ The proposal has not reappeared.

\section{Experience with Complaints under Title VI of the Civil Rights Act of 1964}

Agency regulations implementing Title VI of the Civil Rights Act of 1964 provide that a person who beheves that a recipient of federal financial assistance has discriminated against him on the basis of race, color, or national origin has a right to file a written complaint with the federal agency administering the federal assistance. ${ }^{145}$ These regulations also generally provide for the designation of a "responsible department or agency official" to receive complaints of discrimination. ${ }^{146}$ They further require that recipients of federal financial assistance take reasonable measures to inform the ultimate beneficiaries of their right to complain about discriminatory treatment. ${ }^{147}$ If a complaint is not valid, the responsible agency official designated to receive the complaint must so inform the complainant in writing. ${ }^{148}$ If a complaint is valid, assistance may be terminated ouly pursuant to an express finding of discrimination after an evidentiary hearing with the bases for decision limited to facts of record. ${ }^{149}$

Complaints under Title VI are more likely to involve discriminatory practices in the operation of a program than faulty plans, applications, or other submissions on file with the federal agency. Normally these documents will contain routine assurances of nondiscrimination, and the complaints will allege that grantees are violating these assurances in executing their grants. The United States Commission on Civil Rights ${ }^{150}$ has concluded that the existing mechamism for handling Title VI complaints is confusing and inadequate. The officials responsible for handling complaints do not have sufficient status within their respective

14434 Fed. Reg. 727 (1969).

145 See, e.g., 45 C.F.R. $\$ 80.7$ (b) (1971) (HEW); 24 C.F.R. $\$ 1.7$ (b) (1971) (HUD);

43 C.F.R. $\$ 17.6(\mathrm{~b})$ (1971) (Dep't of the Interior).

146 See, e.g., 45 C.F.R. $\$ 80.13$ (c) (1971) (HEW).

147 See, e.g., 45 C.F.R. $\$ 80.6$ (d) (1971) (HEW).

148 See, e.g., 45 C.F.R. $\$ 80.7$ (d) (2) (1971) (HEW).

14942 U.S.C. $\$ 2000$ (d)-1 (1970).

160 United States Comm'n on Civil Rights, Federal Civil Rights Enforcemeint EFrarT (1970). 
agencies; their salary level is likely to be lower than that of program administrators; and their staffs are often disproportionately small for the task involved. Furthermore, compliance proceedings are frequently protracted, and sanctions are only rarely imposed. ${ }^{151}$

Part A contains no specific reference to complaints of discrimination by grantees of federal financial assistance. Federal agencies may retain under this recommendation separate procedures for handling Title VI complaints while establishing or formalizing new procedures for handling other complaints. Civil rights enforcement is a delicate task that may justify a separate enforcement mechanism staffed by civil rights specialists. In addition, Title VI affords grantees special hearing rights prior to the imposition of sanctions. However, this recommendation should prompt all federal agencies to examine the effectiveness of their existing procedures for handling Title VI complaints. Where those procedures do not conform to the minimum requirements proposed in Part A, appropriate action should be taken to improve the procedures.

\section{The Federal Complaint Procedure and Judicial Review}

Judicial review is becoming increasingly available to persons adversely affected by a federal agency's decision to grant, deny, or terminate federal financial assistance, ${ }^{152}$ although there are still areas where an agency's decision on grant matters is committed by law to agency discretion. ${ }^{153}$ Where the agency holds a formal hearing, the traditional scope of judicial review has been for the court to resolve all questions of law and to determine whether there is substantial evidence on the record as a whole to support the agency's findings of fact. The majority of grant decisions, however, are not subject to the requirements for hearings on the record in sections 7 and 8 of the Administrative Procedure Act, ${ }^{154}$ and the scope of review is consequently more limited. The reviewing court should determine only whether the agency stayed within its statutory authority, observed all procedural regularities, and acted neither arbitrarily nor capriciously on the basis of the record before the court. ${ }^{155}$

An important advantage of an administrative complaint procedure is the opportumity which it offers a federal agency to reassert its pri-

$151 I d_{\text {, }}$ at 702-24.

152 See, e.g., Citizens to Preserve Overton Park, Inc. v. Volpe, 401 U.S. 402 (1971).

153 E.g, Kletschka v. Driver, 411 F.2d 436 (2d Cir. 1969) (termination of Veterans Administration grant).

1545 U.S.C. $\$ 556,557$ (1970).

155 Citizens to Preserve Overton Park, Inc. v. Volpe, 401 U.S. 402 (1971). 
mary responsibility for resolving compliance issues. While the broad trend in favor of judicial review is too widespread to eliminate the courts altogether-and, indeed, there is no reason to think that such a result would be desirable-the complaint procedure should make judicial review necessary in fewer cases and more orderly in those cases where it is necessary. If the agency integrates its complaint procedure into its program administration by considering complaints when making funding decisions, the courts should normally insist that litigants exhaust their administrative remedies and take advantage of the complaint procedure before bringing suit. In many cases the complaint procedure should eliminate the need for court action by satisfactorily resolving the complaint, and in those cases where it does not, the court should have at least the benefit of the agency's views.

It should be emphasized, however, that there is a definite need to safeguard complainants' judicial remedies against grantees, particularly because of the federal agency's discretion not to hear coniplaints. Once formal complaint procedures are established, there is good reason to believe that the courts will require exhaustion of administrative remedies or will find that the grantor agencies have primary jurisdiction to determine questions of compliance with federal standards. In litigation involving claims of nonconformity of state welfare systems with federal law, for example, claims usually are made in a class action suit in federal court alleging a violation of the plaintiffs' federal civil rights under 42 U.S.C. $\$ 1983$. Although the Supreme Court has held that such plaintiffs are not required to exhaust state administrative or judicial remedies, ${ }^{160}$ it has not spoken to the question of federal administrative remedies. Later cases in an analogous area, however, have held that exhaustion of the Equal Employment Opportunity Conimission conciliation procedure ${ }^{15 \tau}$ is necessary before suit can be brought under 42 U.S.C. $\$ 1981$ for discrimination in eniployment. ${ }^{158}$ Such holdings 'suggest exhaustion requirements in the federal grants area as well. Similarly, language in at least one recent Supreme Court opinion suggests that the doctrine of primary jurisdiction might well apply were the federal agency to have a formal complaints process. ${ }^{159}$ In the con-

156 Damico v. California, 389 U.S. 416 (1967) (per curiam).

157 Title VII of the Civil Rights Act of 1964, 42 U.S.C. $\$ 2000$ (e)-5(a) (1970).

158. Waters .t. 'Wisconsin Steel Works, 427 F.2d 476 (7th Cir. 1970). Contra Young ; v. I.T.T., 438 F.2d 757 (3rd Cir. 1971).

159 In Rosado v. Wyman, 397 U.S. 397 (1970), the majority answered the dissent's charge that primary jurisdiction should apply by saying:' "[plaintiffs] do not seek review of an administrative order [there was none], nor could they have obtained an ad- 
text of welfare litigation, it is arguable that once a procedure is established that may be actuated by private parties and in which they may participate, primary jurisdiction lies with HEW to determine the conformity or nonconformity of state plans or the administration of state plans with federal standards. Certainly the question involved is one within the traditional field of agency concern. While such a view might be countered by showing that the issues before the court and the agency differed or that the agency process had no immediate prospects of termination, a strong possibility for the use of the doctrine of primary jurisdiction would remain.

These prospects for the development of judicial review suggest potentially serious difficulties in harmonizing a discretionary administrative complaint procedure with judicial review of state agency action. Conceivably a court could defer to federal agency action while the agency, with no requirement to decide complaints, took no action. Part A seeks to mitigate these difficulties by providing for time limits within which a disposition of some kind must be made on every complaint. Where reasonable time limits for disposition exist, a court which feels compelled to defer to agency expertise could do so without too serious adverse affect on the complainant's interests in speedy resolution of the dispute.

In a more positive vein, a major advantage of the complaint procedure is that the existence of an administrative record is likely to encourage the substitution of review on that record for an evidentiary hearing in the court. This is particularly likely when the federal agency has conducted a full hearing on the issues raised by a complaint. Where a court must review the validity of an administrative determination in the absence of any administrative findings or record, the court has little choice in most cases but to take testimony and to determine the facts for itself. If the administrator has not disclosed the factors he considered or his construction of the evidence, "it may be necessary for the District Court [the reviewing court] to require some explanation in order to determine if the Secretary [the administrator] acted within the scope of his authority and if the Secretary's action was justifiable under the applicable standard." 160 To that effect, the reviewing court

ministrative ruling since $\mathrm{HEW}$ has no procedure whereby welfare recipients may trigger and participate in the Department's review of state welfare programs." Id., at 406. The negative implication is that if $\mathrm{HEW}$ did have an administrative procedure which could be triggered by recipients and in which they could participate, then the court might have a different view toward the appropriateness of litigation in federal district court.

160 Citizens to Preserve Overton Park, Inc. v. Volpe, 401 U.S. 402, 420 (1971). 
may require "the administrative officials who participated in the decision to give testimony explaining their action," even though such testimony involves an inquiry into the mental processes of the administrative decision-makers. ${ }^{161}$

Extensive hearings and testimony of this type can often be avoided if a federal agency provides the reviewing court with a contemporaneous administrative record resolving complaints about the project and defending any decision to proceed. If the reviewing court is furnished with an adequate explanation of the agency's decision, it should not hold an evidentiary hearing but should review the record to ensure that the agency stayed within its statutory authority, observed all procedural regularities, and acted neither arbitrarily nor capriciously. ${ }^{162}$ Judicial review thus limited in scope should, on the whole, work to the advantage of the agency. The prospect of judicial review should also encourage the official designated by the federal agency to resolve complaints to state in writing the reasons for his decision and any determinations of fact which he has made. Absent a showing of bad faith or improper behavior, there can be no inquiry into the mental processes of the administrative decision-maker if he makes formal determinations of fact. ${ }^{103}$

\section{The Implementation of Part A: A Case Study of Urban Renerwal}

The implementation in the urban renewal program of the administrative conplaint procedure proposed in Part A is both feasible and desirable. While there is no doubt that the implementation of this procedure will require additional effort on the part of HUD, the added burden must be balanced against the overall benefits accruing to urban renewal from the procedure. These benefits are basically the same as those discussed in the general comnentary to Part A, that is, the more effective enforcement of federal standards, the strengthening of the role of the federal agency, the reduction of interference from the courts, and the improved handling of citizens' grievances. In addition, the complaint procedure should improve the decisional process employed by HUD for allocating scarce urban renewal funds.

161 Id. An extreme example of such an inquiry occurred recently in D.C. Federation v. Volpe, 316 F. Supp. 754 (D.D.C. 1970), rev'd on otber grounds, 434 F.2d 436 (D.C. Cir. 1971), where Secretary of Transportation Volpe personally testified for five hours. concerning his release of federal funds for bridge construction involving the use of: parklands.

162 Citizens to Preserve Overton Park, Inc. v. Volpe, 401 U.S. 402, 415-17 (1971). $1631 d$.; at 420 . 
The most appropriate time for persons affected by an urban renewal project to file complaints directed at the project is when HUD is reviewing the part I loan and grant application. The local public agency (LPA) normally must submit factual data to show its compliance with federal standards, and it is at this point that complainants should be able to challenge the LPA's data on the grounds that it is inaccurate or insufficient. For instance, a complaint may challenge an LPA's description of the housing resources in the community available to displacees or an LPA's finding that the condition and debt-carrying capacity of dwellings in the project area make their rehabilitation feasible. Potential displacees or owners of the dwellings to be rehabilitated may be able to show that the housing market in the commumity is much tighter than portrayed by the LPA or that the owners of the dwellings are not likely to obtain the financing needed to make rehabilitation feasible. ${ }^{164}$ Complaints directed at survey and planning applications present more difficulties, because the application may be too sketchy to permit an effective challenge and may be eliminated altogether if the LPA elects to use local funds for its planning process. Nevertheless, it is desirable to process coniplaints at this early stage. A survey and planning application must establish the eligibility of the project area and must demonstrate that the project meets one of the national goals (or is exempt therefrom). ${ }^{165}$ Affected persons opposed to a project proposed in a survey and planning application may complain that the project area is not eligible for urban renewal treatment because it is neither a slum nor a deteriorated area or that the project does not meet any of the national goals. These complaints should be resolved promptly so that projects which fall short of these basic federal standards are never begun.

All complaints of noncompliance with federal standards should be resolved before a loan and grant application is approved and the project funded through a loan and grant contract. If the complaints are not resolved at this stage, they will probably arise again in the midst of project execution, when the opponents of the project seek to stop the

164 Similarly, persons affected by renewal activity should be able to file complaints: when an LPA submits a Neighborhood Development Program application for an annual increment for an action year or an amendatory loan and granit contract to expand 2 . conventional urban renewal project.

165 HUD normally gives priority treatment to projects that meet specific criteria for the conservation and expansion of low and moderate income housing or for the development of new employment opportunities. URBAy ReNEwal HANDBook, RHM $7202,1(2)$ 
project through a lawsuit. If complainants do not avail themselves of the administrative complaint procedure at the application stage, doctrines of exhaustion or waiver should preclude them from later challenging the project in court, unless there was good reason for their failure to present their complaints at the application stage.

A major benefit which should accrue to the urban renewal program from the introduction of an administrative complaint procedure is an improved allocation of urban renewal funds. HUD must allocate limited resources among competing applications in a way that will best further national housing goals. These goals are reflected in the federal standards that accompany urban renewal project grants. Broadly speaking, the purpose of these standards is to ensure that an urban renewal project contributes to the supply of decent housing and to a decent environment and does so in a way that does not disproportionately injure the residents of the project area. The enforcement of these standards is often difficult, because cities embarking on urban renewal projects may have different interests, such as the beautification of the central business district, the increase of the tax rolls, or the economic well-being of local real estate and redevelopment industry. These interests may conflict with the federal standards and with the interests of project area residents.

The availability of an administrative complaint procedure should assist HUD in the allocation process by providing more complete information. The complaint procedure should involve in the grant process affected third parties, acting in many cases as private attorneys general. These private attorneys general may provide HUD with new perspectives on the facts and with an independent source of information, thus preventing too intimate and friendly a relationship from developing between HUD and LPAs applying for federal funds. Based on the added information, HUD should be able to reject applications that do not meet federal standards when it might otherwise have approved the applications because the noncompliance with federal standards went undetected. For example, the Comptroller General has documented the collapse of a major urban renewal rehabilitation project in Cleveland which never should have been approved, because rehabilitation by the property owners was not economically feasible. ${ }^{106}$ An administrative complaint procedure should help the agency avoid similar mistakes in the future.

166 Comptroluer General's Report to the Congress, More Effective Federat, Action Nizded to Meet Urban Renewal Rehabilttation Objectives in Cleveland, Oho (1968). 


\section{B. The Grantee's Administrative Complaint Procedures ${ }^{167}$}

The federal grantor agency should require as a grant condition the establishment by the grantee of procedures to handle complaints concerning the grantee's operation of the federally assisted program. These procedures should afford any person affected by an action of the grantee in the operation of the program a fair opportunity to contest that action. The "fair opportunity" to contest will necessarily vary with the nature of the issues involved and the identity and interests of the complainant. In all cases, however, the complainant should have the right to submit to the grantee for its consideration data and argument in support of the complainant's position. Where it is claimed that the action which is the basis for the complaint deprives the complainant of any individual benefit or protection to which he is entitled under the grant-in-aid program, the grantee should afford the complainant an adjudicatory hearing on all contested issues of fact.

Part B proposes that the federal grantor agency require as a grant condition the establishment by the grantee of administrative procedures to handle complaints concerning the grantee's operation of a federally assisted program. Such a complaint procedure should assist in achieving compliance with federal standards by providing a formal, publicized mechanism whereby affected persons may inform the grantee of potential violations of federal standards and may obtain a hearing on their complaints. The grantee, having learned of a violation, should in the great majority of cases correct the situation voluntarily. Where the grantee refuses to acknowledge a violation of federal standards, the complaint procedure should nevertheless alert both the grantor and the grantee of a potential compliance problem. The federal agency should be able to obtain an overview of the compliance situation by momitoring a grantee's complaint procedures or by requiring periodic reports by the grantee. In addition, an effective complaint procedure should improve the quality of a grantee's program and should make the program more responsive to the concerns of the ultimate beneficiaries.

The complainants who take advantage of the grantee's complaint procedures are likely to be individuals with specific grievances. Parts $A$ and $B$ both recognize the need for procedures for handling this type of complaint where the grievance arises, rather than at some remote

167 The Administrative Conference deleted the last sentence of Part B as superfluous. Administrative Conference of the United States, Recommendation 31: Enforcement of Standards in Federal Grant-in-Aid Programs (adopted December 7, 1971). 
federal office building. The complainant adversely affected by the action of a state or local government or private organization is most likely to direct his grievance to that body. He may not even be aware that federal funds support the action which is the basis of the complaint and is unlikely to think of directing his complaint initially to the federal agency. The complainant is only interested in getting his normal check from the city welfare department or in convincing the state highway department to provide him with additional relocation assistance. His contacts have been entirely with officials of state or local agencies or of private organizations in the community, and he naturally turns to those officials with his complaint. Those officials are the appropriate ones to handle his complaint, because action to remedy the situation which led to the complaint is most likely to come from them. They have ready access to the information necessary to determine the validity of the complaint and should have the ability and authority to act quickly where the complaint is valid. For these reasons Part A provides that the federal agency should normally refer to the grantee any complaints of individual mistreatment.

Part B provides that a grantee's complaint procedures should handle all types of complaints by persons affected by the grantee's federally assisted activities and shonld not be limited to complaints that a grantee is violating federal standards. The principal consideration supporting the broader coverage is the ignorance of most complainants of the real basis for their complaints. The complainant believes that he has been hurt by the action of some city or state department. Often the contplaint may be unfounded. The complainant's real need may be for adequate information. ${ }^{168}$ Even if the complaint is justified, the complainant may not know enough about the operation of the program to articulate how the action complained of violates federal, state, or local requirements. The complainant is probably unaware of any federal standards involved and is therefore unable to formulate his complaint in terms of a violation of these standards. The grantee's complaint procedure shonld therefore cover all types of complaints and should perform, in addition to a remedial function, an informational and referral one. Thus, if a complaint is directed to the wrong body, the state or local agency or private organization which receives the complaint should dispose of it by directing the complainant to the appropriate place.

168 See W. Gellhorn, When Americans Complain: Governmental Grievance Procedures 153-56 (1966). 


\section{Structure of the Grantee's Complaint Procedures}

Part B allows grantees to structure their own complaint procedures, subject to the requirement that the procedures afford a complainant affected by an action of the grantee a fair opportunity to contest that action. The plural "procedures" is used throughout the recommendation to emphasize that grantees may develop alternative complaint procedures to handle different types of complaints. For example, complaints of corruption may be referred through prescribed channels to an official watchdog, while complaints of improper termination of statutory benefits may be handled in accordance with distinctly different procedures. The need for flexibility is particularly strong where state and local governments are grantees. The structure of state and local government itself varies greatly throughout the country, and each grantee government should have some range of choice concerning how best to integrate any new complaint mechanism into the existing governmental structure. In most cases, the existing structure will already include some mechamism for the handling of citizen's grievances. Furthermore, most state and local governments participate in a number of federal programs and should have the authority to coordinate or combine the complaint procedures for these programs.

Part B contemplates an internal complaint mechanism run by the grantee or a separate agency established by the state or local government to handle complaints concerning a number of programs. In each instance, that agency should have authority to resolve complaints and not just to bring administrative abuses to the attention of the public. ${ }^{169}$ The purpose of the complaint mechanism is both to provide adequate information to all complainants on the nature of the program and to redress those individual complaints that are justified.

A grantee's operation of a federally assisted program is likely to engender a broad variety of complaints, such as complaints of rudeness or discourtesy by grantee officials, complaints that a grantee's mode of operation unnecessarily injures the complainant, complaints that the grantee is harassing the complainant, and complaints that the grantee has improperly deprived the complainant of an individual benefit or

169 Unlike numerous recent discussions on the redress of citizen's grievances, this is not a proposal for an "ombudsman." The path-breaking work on this topic is W. Grulhorn, When Americans Complain: Governmental Grievance Procedures (1966). For other literature on the ombudsman issue, see S. ANDERson, OMBUDSMAN FOR American Government? (1968); Tibbles, The Ombudsman: Who Needs Him? $47 \mathrm{~J}$. OF URBAN L. 1 (1969). 
protection to which he is entitled under the grant-in-aid program. The type of hearing which the grantee should afford the complainant should depend on the nature of the issues involved and the identity and interests of the complainant. In all cases the complainant should have the right to submit data and argument in support of the complaint, either in the form of written submissions or through an informal oral presentation to an official of the grantee.

Where the complainant claims that the grantee has deprived him of welfare benefits, a tenancy in public housing, or any other individual benefit or protection to which he is entitled under the grant-in-aid program, due process requires that the grantee afford the complainant an adjudicatory hearing on all contested issues of fact. ${ }^{170}$ Unfortunately, judicial decisions do not delineate the precise scope of this requirement. Unsettled questions remain concerning whether due process requires an adjudicatory hearing when there is an initial demal or later reduction of benefits or when the benefit at stake does not have the same crucial importance to the recipient as do welfare benefits or public housing. ${ }^{171}$ Similarly, the law is unclear as to the extent to which the due process clause requires private grantees to afford hearings to ultimate beneficiaries of a grant program who are adversely affected by a grantee's action. ${ }^{172}$

Federal grantor agencies should react affirmatively to this uncertain situation by defining the classes of cases where fairness requires that the grantee afford the complainant an adjudicatory hearing on contested issues of fact. On the one hand, complaints about the location of a highway do not involve the deprivation of any individual benefit or entitlement but raise policy issues about the merits of the particular highway. On the other hand, a homeowner's eligibility for relocation benefits or the amount to which he is entitled deserves different treatment. In these latter situations federal grantor agencies should not force complainants to go to court to assert their rights to an adjudicatory hearing but should require as a grant condition that the grantee afford

170 Goldberg v. Kelly, 397 U.S. 254 (1970) (welfare benefits); Escalera v., New York Housing Authority, 425 F.2d 853 (2d Cir. 1970) (public housing).

171 O'Neil, Of Justice Delayed and Justice Denied: The Welfare Prior Hiearing Cases, 1970 Supreme Court Rev. 161, 202-13.

172 The cases in this area have generally involved tenants in federally subsidized private housing developments. See Langevin v. Chenango Court, Inc., 447 F.2d 296 (2d Cir. 1971) (tenants not entitled to a hearing on rent increases even though there were adjudicative facts involved); McQueen v. Drucker, 317 F. Supp. 1122 (D. Mass. 1970) (evicted tenant entitled to a hearing on whether the landlord had "good cause"), aff'd on otber grounds, 438 F.2d 781 (1st Cir. 1971). 
such a hearing to complainants. In defining those cases where adjudicatory hearings are necessary, the federal agency should not limit itself to minimum due process standards as defined by the courts but should go further and draw upon its broad knowledge of its own grant-in-aid programs to determine those categories of cases where formal adjudicatory hearings would be desirable.

Because of the impact on grantor agencies in terms of work load and the difficulties of accommodating federal agency review with state judicial review, disappointed claimants in a grantee proceeding should not normally be permitted to appeal an adverse decision to the grantor agency. Taking AFDC as an example, there are difficult problems in trying to correlate state judicial review ${ }^{173}$ with federal administrative review. Assuming, as is customary, that the unsuccessful complainant in a fair hearing has raised issues both of the interpretation and the application of the state regulations or statutes, as well as their conformity to federal requirements as interpreted and applied in his case, he will have both federal and state grounds for review. His federal ground can, of course, be raised in a state court review proceeding. But were there also an appeal in individual cases to HEW, it is unlikely that the Department of Health, Education and Welfare would take the responsibility for finally determining the interpretation of state law. Hence, in review by HEW the state department's interpretation would have to be followed. Knowing this the claimant might concurrently pursue a state judicial remedy involving the state in two separate procedures. Indeed, the plaintiff might be required to pursue state judicial remedies first, since it is arguable that HEW should not make a conformity ruling where there is a contested issue of interpretation of state law. Assuming that state remedies were first pursued, should the claimant be allowed to omit from his state review claim the claim that federal law is being violated? If so, he would be able to pursue the state on that question through the HEW administrative remedy should he lose on his state law grounds in the state court. Alternatively, if he should raise, or be required to raise, the federal question in the state court proceeding and lose on that issue, would he then be barred on res judicata grounds from pursuing the administrative remedy established by the federal department?

The grantor and grantee complaint procedures here proposed avoid

$173 \mathrm{~A}$ search of state statutes indicates that in thirty states there is 2 clear right to judicial review of an adverse public assistance determination; in thirteen states there seems to be a prohibition of judicial review, and in seven states the situation is unclear. 
these potential pitfalls by separating the two procedures and by making the federal grantor procedure discretionary. Complainants alleging substantial noncompliance or noncompliance in areas of particular federal concern, such as nondiscrimination, may proceed directly to the federal complaint procedure, while individual complaints in other cases should be lodged with the grantee. Of course, nothing prohibits an individual complainant from filing a complaint with the grantor, should he be dissatisfied with the grantee's determination and have grounds for asserting the existence of substantial noncomphance or of a strong federal interest. The federal grantor agency would have discretion to decline to process complaints having this sort of history should the agency consider resort to state judicial review more appropriate.

\section{The Need for Effective Grantee Complaint Procedures}

In view of "the increasing involvement of government officials in the lives of citizens, adequate procedures for the consideration of such individual grievances as citizens may have against such officials are essential to effective government." ${ }^{174}$ Unfortunately, the existing procedures for redressing citizens' grievances are inadequate. The Kerner Commission, for instance, found that the lack of an accessible and visible means for establishing the merits of grievances against agencies of state and local government was a source of tension and frustration among ghetto residents. ${ }^{175}$ Recent proposals to establish the office of ombudsman have also been based on the belief that existing mechanisms for handling complaints are inadequate. 'Citizens' complaints are presently handled primarily by elected' legislative and executive officials who consider the task a service to their constituents. Only rarely do either watchdog executive agencies or formal administrative complaint procedures within operating agencies play a significant role. The federal government should take some initiative to ensure that complaints directed at the operation of federally assisted programs are properly resolved.

The considerations that support grantee complaint procedures for governmental bodies are not fully applicable to private grantees. In addition, these private grantees may find unfamiliar their new role of resolving grievances. While state and local governments are accuistomed to: this role because they have always necessarily" recognized their

174 President's COMM'N ON LAW ENForCEMENT AND the AdMINISTRATION OF JUSTICE, The Challenge of Crime in a Free. Society 103 (1967).

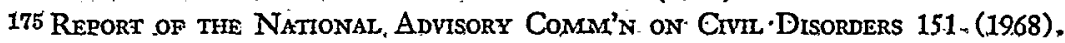


accountability to the governed, private organizations tend to view themselves as more independent and not responsible to a constituency. Part B nevertheless recommends that both public and private grantees develop administrative complaint procedures. ${ }^{176}$ It would be incongruous for the federal grantor agency to require some grantees to establish complaint mechanisms but not require others to do so. The dividing line between public and private in these areas is too blurred to support such a distinction. Community action agencies, for example, may be governmental units or public agencies or private nonprofit organizations; but if they are nonprofit organizations, they must be formally designated as a community action agency by a governmental unit. In all cases the community action agency is performing a public function. Most privately endowed hospitals and universities that receive federal grants likewise recognize that they are performing a public function and that they have responsibilities to the public at large. In order to obtain federal grants, these institutions must normally work through a state health or education agency that has developed a comprehensive state plan for meeting the state's responsibilities in the area. Private grantees that are not prepared to operate their own complaint procedures may assign the task to the state agency and direct to it all complaints concerning their operations. In many programs it would seeni sensible for the state agency to handle complaints directed at both public and private grantees and in this fashion to centralize the complaint process. Whether such an arrangement would remove the complaint procedure too far from the source of the complaints depends on the balance of state and local involvement in the particular grant program.

\section{Part $B$ and Existing Agency Practices}

The HEW experience suggests that the difficulties in structuring an appropriate complaint procedure at the state level may be considerable. These difficulties may involve the federal government in extensive regulation of the state complaint procedure and in attempts to enforce additional federal standards. This is not necessarily to say, however, that the game is not worth the candle.

The Department of Health, Education and Welfare has extensive experience with state grievance procedures. Since 1935 Title IV of the

176 The grant-in-aid programs involving substantial numbers of private grantees which are covered by this recommendation are, in addition to subsidized private housing developments, in the health, education, and antipoverty areas. 
Social Security Act $^{177}$ has required that states employ a "fair hearing". procedure whereby disappointed claimants of public assistance may. appeal a determination of ineligibility, reduction of grant, or more recently, failure to act with reasonable promptness upon a grant request. The legislative hearings on the 1935 Social Security Act ${ }^{178}$ reveal that there was little understanding in Congress or the Social Security Board concerning what the "fair hearing" requirement would mean. Everyone understood that it would require some kind of review beyond an initial administrative determination, but the administration's witnesses, testifying before the House Ways and Means Committee, indicated that the federal government through the Social Security Board would promulgate no standards beyond those contained in the statute concerning what might constitute an appropriate fair hearing procedure. According to the administration, the standard for reviewing state plans in the Social Security Board would be whether the state proceedings were "utterly unfair." Congressman Vinson, however, did not accept the approach of "leave it to the states, they will be fair." If this were true, Vinson thought that the Congress might as well omit the fair hearing requirement altogether. HEW has over the years come to the Vinson view that considerable further regulation is necessary in order to have an effective fair hearing procedure. ${ }^{178}$

By 1968 the Handbook of Public Assistance Administration required the states to meet twelve basic conditions in establishing a fair hearing proceeding. ${ }^{180}$ The fundamental nature of most of these requirements gives some idea of the resistance that HEW must have encountered from the states. The requirements include, for example, the following: (1) that decisions of the hearing authority be binding on state and local agencies, ${ }^{181}$ (2) that hearings be conducted by an impartial official of the state agency, ${ }^{182}$ (3) that in the presentation of his case the claimant be allowed to make the presentation himself or with the aid of others,

17742 U.S.C. $\$ 602(a)(4)(1970)$.

178 Hearings on H.R. 4120 Before the House Comm. on Ways and Means, 74th Cong., 1st Sess. (1935).

179 The only amendment to the statutory fair hearing language has been the addition of provisions in 1950 which require "fair hearings" where an applicant's request for benefits ". . . is not acted upon with reasonable promptness." Social Security Act Amendments of 1950, ch. 809 321(a), 64 Stat. 477, 479. Nonetheless, the regulatory activity has been extensive in recent years.

180 The Departanent of Health, Education and Werfare, The Handbook of Public Assistance Admistration, Part IV, 6200 (February 8, 1968).

181 Id., at $\$ 6200$ (i).

182 Id., at $\$ 6200$ (d). 
to bring witnesses, to establish all pertinent facts and circumstances, to advance any and all arguments without interference, and to question or refute any testimony or evidence put forth by the state or local agency. ${ }^{183}$

Even requirements such as these proved insufficient. Pending the decision in Goldberg v. Kelly, ${ }^{184} \mathrm{HEW}$ promulgated regulations, to take effect July 1, 1970, which would have required continuation of assistance payments until the completion of any fair hearing raising an issue of fact or judgment concerning the application of state policy to the facts of an individual case and that the services of lawyers be made available to welfare applicants and recipients who desired them in fair hearings. Goldberg v. Kelly found the first requirement a part of minimum due process in the determination of public assistance claims but failed to require the provision of legal services. After the Goldberg decision, and in connection with a general codification of the Handbook of Public Assistance Administration requirements into 45 C.F.R., HEW promulgated more explicit requirements concerning the continuation of assistance but withdrew the requirement that legal services be provided. The new regulations, which took effect April 14, 1971, do little more than codify the pre-existing Handbook requirements with the addition of those due process requirements set forth in Goldberg and not previously included in the Handbook, to wit, that a claimant be afforded an opportunity for confrontation and cross-examination of adverse witnesses and that the decision-maker, in order to demonstrate compliance with the requirement of decision on the record, state the reasons for his determination and indicate the evidence upon which he relied. Some of the other requirements previously in the Handbook are further explicated in the new regulations, and there is the new requirement that, if requested, a state agency must provide a group fair hearing on issues of state policy.

All of these requirements for fair hearings are obviously thought by HEW to be necessary to make meaningful the statutory requirement that a state plan have a fair hearing procedure. The federal agency found that it could not simply require a hearing and expect that the states would themselves establish hearing processes which fit the particular needs of the welfare clientele and of the issues raised by welfare claims.

Unfortunately, the problem of securing a viable state complaint 
procedure does not end with stating requirements. Recent studies suggest that there may be massive noncompliance by the states with the federal requirements. A study of the fair hearing process in all of the states by Robert E. Scott, ${ }^{185}$ for example, found that state compliance with twelve requirements bearing directly on the fairness and availability of the hearing process ranged from seventy-five per cent to twenty-five per cent compliance. ${ }^{186}$ In a survey conducted for purposes of this Article of the states comprising Region III of HEW, ${ }^{187}$ similar noncompliance was discovered. For one reason or another, every state in the region is out of compliance with federal law on at least one requirement concerning access to the fair hearing procedure or the actual fairness of the procedure. In most states there are substantial limitations on fair hearing rights as defined by federal regulation. Moreover, the fact that a state handbook or statute carries a provision which apparently complies is no guarantee of actual compliance. In Virginia, for example, there is no substantial compliance in some local offices with the requirements for oral explanation of appeal rights, aid in preparing an appeal, or availability of previous fair hearing decisions, although the state manual contains requirements on all of these counts. ${ }^{188}$

The HEW experience suggests that there will probably be resistance on the state or local level to the establishment of a grantee's complaint procedure. It seems likely, therefore, that the type of hearing that should be required, at what time, with what procedure will have to be spelled out in detail by the federal agency in order to have any real impact on the operations of the grantee. Moreover, because of its

185 Scott, The Regulation \& Administration of the Welfare Hearing Process-The Need for Administrative Responsibility, 11 W. \& M. L. REv. 291 (1969).

186 Indeed, there is reason to believe that even these percentages vastly overstate the actual compliance with federal regulations. They are based wholly on an analysis of the language of the statutes and regulations and do not account for the substantial noncompliance which may result from the administration of the system by state welfare officers.

187 R. Stevens \& D. Kirstein, Regional Office Administration, 1971, (unpublished paper) on file at the Virginia Law Review.

188 See Mashaw, Welfare Reform and Legal Administration of Aid to Families with Dependent Cbildren in Virginia, 57 VA. L. REv. 818 (1971). The HUD experience has been similar to that of HEW. HUD has also defined precise grievance procedures which local housing authorities (LHA's) must afford their tenants. When the tenant contests an action, he must be provided an opportunity to present his side of the dispute before an impartial official or before a hearing panel. The tenant has a right to call wituesses, to be represented by counsel of his choice, and to confront wituesses. The official or.panel that conducts the hearing must notify the tenant of its decision and its findings of fact and law. See Lefcoe, HUD's Autbority to Mandate Temant's Rigbts in Public Housing, 80 YaLE L.J. 463 (1971). 
impact on grantee compliance with federal standards in general, the requirements for grantee complaint procedures should be a priority item in the grantor agency's enforcement program. Individual complaints concerning the grantee complaint procedure should be treated as "important for the effectuation of federal policy" for purposes of the grantor's complaint process.

\section{The Information System ${ }^{189}$}

The federal grantor agency should ensure that persons affected by a grant-in-aid program receive adequate information about the program, in order that they may take advantage of the federal and the grantee complaint procedures. The federal grantor agency should require as a grant condition that all program materials (regulations, handbooks, manuals, etc.) governing the grantee's administration of a program supported in whole or in part by federal grant-in-aid funds and all plans, applications, and other documents required to be submitted to the federal agency as a condition to the receipt of federal funds should be readily accessible to persons affected or likely to be affected by the operation of the funded program. Plans, applications, and other documents that provide the basis for federal funding should be made readily accessible to interested persons no later than the time of their submission to the grantor agency for approval and at an earlier time when required by law.

The federal grantor agency should ensure that the grantee's system for dissemination of program materials and grant submissions takes account of the nature, location, and representation of affected persons. For example, as a part of a plan to make such materials readily accessible, program information might be deposited not ouly in the offices of the grantee but also in public and university libraries and in the offices of affected interest groups and their legal representatives. It might also be necessary to require descriptive summaries of technical rules or project applications or to require an oral explanation of program features (for exainple, the complaint procedure) which are critical to the protection of a beneficiary's interests. The federal agency should make parallel efforts to disseminate materials relating to its administration of the federal grant program.

Part $\mathrm{C}$ of this recommendation recognizes that, in order for a complaint procedure to be effective, the affected populace must have

189 The Administrative conference has slightly altered the language of Part C. ADministrative Conference of the United States, Recommendation 31: Enforcement of Standards in Federai Grani-In-Am Programs (adopted December 7, 1971). 
adequate and timely information concerning both the federal grant program and the grantee's or potential grantee's participation in that program. Only if this information is available will affected persons be able to determine intelligently whether there is any basis for a complaint that federal standards have not been met. Part $C$ is directed specifically at aspects of the general problem of accessibility of information which are particularly relevant to the adequate functioning of complaint procedures. It does not deal, except incidentally, with pubhic information issues which might arise in the context of implementing general policies for broadening public participation in agency decision-making or for better informing potential grantees of the availability of federal funds.

The basic information component for an effective complaint procedure is the accessibility of documents which govern the administration of the funded program by both the grantor and the grantee. At the federal level these documents will include the applicable statutes, regulations, agency handboolks or manuals, and any descriptive literature or orders which contain agency interpretations or opinions concerning the proper administration of the relevant grant program. Similar documents describing the grantee's operations should also be made accessible. In addition, affected persons should have access to any plans, applications, reports, or other documents which a grantee is required to submit to the federal grantor agency as a basis for initial or continued federal funding.

Part C covers ouly documents that are current; it is not intended to affect a grantor's or grantee's policy with respect to the preservation and storage of outdated plans or applications that are no longer operative. The documents covered by the recommendation are generally public; they almost never contain confidential material, and, when filed with the federal agency, they are generally obtainable from it by any person under the Freedom of Information Act. ${ }^{190}$ Present procedures already provide a means by which many of them are easily made available for public inspection. For example, plans and applications of governmental grantees are generally made pubhic at the state or local level before they are submitted to the federal agency, since they normally must be approved by the relevant units of state and local government. Project applications for construction and developmental grants also must be cleared with state, regional, or metropolitan planning councils in order to assure area-wide coordination of federal assist-

190.5 U.S.C. $\$ 552$ (1967). 
ance programs. ${ }^{101}$ This process of clearinghouse review assures that at least those persons within the grantee fraternity or with contacts at the state or local government level will be aware of plans and applications that are pending or in effect. In addition, a significant nunber of federal assistance programs require that there be public hearings on individual project applications or that private citizens participate in the overall planning process for the federal grant.

Part $C$ supplements these existing mechanisnis and seeks to ensure that in all cases persons affected by a grant-in-aid program receive adequate information about the operation of the program, in order that they niay take advantage of the federal and the grantee conplaint procedures. The recommendation also recognizes that the simple availability of the relevant documents may not be adequate to inform affected persons of the requirenients surrounding the administration of the funded program. Hence, it may be necessary to require special techniques for the dissemination of this information.

\section{Information Accessibility as a Grant Condition}

Part $\mathrm{C}$ provides for the accessibility of information by attaching a condition to the federal grant. The operational responsibility will therefore be on the grantee to make its program materials and submissions accessible in accordance with whatever specific requirements are contained in the grant condition. The federal grantor agency should impose similar requirements upon itself with respect to the accessibility of federal program materials and should make parallel efforts to disseminate those materials.

This means for dissemination of grantee program material and submissions was chosen because it is likely to be more effective than the only available alternative, federal grantor dissemination. The grantee will necessarily be better equipped, due to the proximity of its operations to the affected populace, to make the relevant information accessible. Moreover, to charge federal grantor agencies with the collection and dissemination of all grantee program materials and submissions would be extremely burdensome and would conflict with emerging federal policies for the simplification of the grant application process by the use of proclaimers. The resources of the federal agency devoted

191 See Bureau of the Budget, Revised Circular A-95 (Feb. 9, 1971) which implements $\$ 204$ of the Demonstration Cities and Metropolitan Development Act of 1966, 42 U.S.C. $\$ 3334$ (1970), and Title IV of the Intergovernmental Cooperation Act of 1968, 42 U.S.C. $\$ 4222(1970)$. 
to enforcement of grantee compliance with federal standards can almost certainly be better utilized in the investigation of critical compliance areas and in the investigation and resolution of complaints concerning state systems than in handling thousands of pieces of paper reflecting every modification of grantee regulations. Of course, to the extent that the federal agency has relevant documents concerning the grantee's program on file, it should make them accessible to interested parties in conformity with the Freedom of Information Act ${ }^{192}$ and Administrative Conference Recommendation No. $24 .{ }^{193}$

\section{Time of Availability}

It is important that adequate information concerning a grantee's plans, applications, or other submissions that provide the basis for federal funding be available at an early stage in the funding process. This will facilitate objections by affected parties at a stage where the federal agency is best able to obtain compliance with federal standards. The resolution of compliance questions at this early stage is not likely to disrupt the grantee's operations. The recommendation suggests that the latest the information should be disseminated is the time of submission of any plan, project application, or other document for approval by the federal agency. The suggestion that information be accessible to the public at the time of submission for approval is, of course, a minimum standard and is not meant to replace any existing requirements for earlier accessibility, for example, in connection with required public hearings or other citizen participation.

"Approval," as used in the recommendation, does not necessarily mean final approval of a project. Final approval may come at a very late stage in the grant process and after a series of prior approvals of various steps in the project. Nor does "approval" necessarily connote an action which definitively commits federal funds. Such a commitment occurs in the federal-aid-highways program, for example, only after submission of plans, specifications, and estimates. This submission may occur years after initial approval of a highway department's decision on the location of a project. A submission for approval under this recommendation includes any submission which is required as a

1925 U.S.C. $\$ 552(1970)$.

193-Administrattve Conference of the United States, 1970-71, Report 52, Recommendation 24: Untforme Procedures for Implementing The Freedom of Information Act (adopted June, 1971). 
part of the process of approving the initiation or continuance of federal funding. 194

It should be recognized that a requirement of accessibility of grantee plans and project applications at the time of their submission for approval will have different effects in certain formula grant programs than it will in project grant programs. In the case of formula grants for categorical public assistance programs, for example, the provisions of a state's plan will normally be submitted for approval after those provisions have gone into effect as a part of the state's statutory or regulatory scheme. Any complaint concerning such a submission thus will be directed to a finding that state law is out of compliance with federal standards, rather than, as in the project grant context, at a finding merely that the application is not acceptable in its present form. Consequently, the complaint mechanism may be somewhat less useful for formula grants than for project grants. In the former case the affected parties are likely to be informed of the grantee's policies after decisions have been made and to some degree implemented, rather than while positions are still fluid.

This difficulty might suggest that some special provisions for informing the public be made in those programs where changes in state law or regulations are systematically translated into amendments to state plans, or indeed, in any situation where the grantee's program policies become effective prior to their submission for federal grantor approval. Any such recommendation, however, would have extensive consequences concerning public participation in grantee decision-making in general and should be approached from that perspective. This Article thus does not attempt to answer the questions of what form such participation should take and how federal requirements might be coordinated with state administrative procedure acts.

\section{The Form of Information and Tecbniques for Making It Accessible}

Because Part $\mathrm{C}$ covers a large number of relatively disparate grant programs, there has been no attempt to provide detailed guidelines for public information programs. Rather, the recommendation seeks to present a series of considerations which should animate both the federal agency's efforts to disseminate information concerning the federal pro-

194 This generally accords with the notions of finality that have been employed by federal courts in judicial review of agency actions. See, e.g., Named Individual Members of the San Antonio Conservation Soc'y v. Texas Highway Dep't, 446 F.2d 1013 (1971). 
gram and the public information requirements it imposes on its grantees. The basic consideration is adequacy of information with respect to utilization of the complaint procedures. In developing an adequate program of public information, the federal agency should also consider the "nature, location and representation" of the persons with whom it seeks to communicate and, of course, the nature of its particular program.

Federal Agency Efforts-A recurrent difficulty in dealing with federal grant programs is the discovery of what the federal standards are which condition the receipt of federal grant moneys. In part this difficulty stems from the failure of grant agencies to use the informal rule making procedures of the Administrative Procedure Act, including publication of standards in the Federal Register. ${ }^{105}$ The result is that federal standards may be contained in compilations ranging from the Code of Federal Regulations to informational circulars distributed only to grantees. Certain agencies, such as HEW, have made considerable progress in putting mandatory federal grant standards into regulatory form and publishing them in the Federal Register. Other agencies, such as the Federal Highway Administration, have not done nearly so well. FHWA policies are still largely contained in a series of administrative, instructional, and policy and procedure memoranda which are, to say the least, difficult to use. Moreover, most grant or agency handbooks, manuals, and circulars contain everything from mandatory standards to helpful hints. In order adequately to inform interested persons concerning the operation of federal grant programs, many agencies should conform to previous recommendations of the Administrative Conference of the United States concerning the use of the Federal Register for the publication of mandatory standards and compile all their directory materials into a single set of policy guidelines clearly labelled as to their intended effect. The federal agencies also should be attentive to details, such as subject-matter indexing, descriptive synopses, and identification of available "public information" personnel, which may make the difference between effective and ineffective commumication of the substance of federal requirements.

In part the failure to put grant standards into a documentary form more readily accessible to the public may be the result of a mistaken

195 See, Administrative Conference, of the UNIted States, I Recomimendations aNd Reports 305 (1970), Recommendation 16: Elimination of Certain Exemptions from the APA Rulemaking requirements; AdmINISTRATIVE CONFERENCE OF THE UNIEd States, 1970-71 Report 58, Recommendation 26: Minimum Procedures for Agenctes AdMinistering Discretionary Grant Programs (1970). 
notion on the part of federal agencies as to the impact of federal grant conditions on the rights and privileges of intended beneficiaries. The Federal Highway Administration, for example, has adopted a regulation stating that its memoranda setting forth requirements for grantees provide no rights or privileges not explicitly set forth therein. ${ }^{196}$ Yet, surely the teaching of cases such as Barlow $v$. Collins ${ }^{197}$ is that persons adversely affected may rely upon federal grant standards as a basis for challenging agency action, even in situations where they have no individual entitlement at stake. Cases involving judicial review of highway grant decisions by the FHWA have, since Road Review League $v$. Boyd ${ }^{198}$ consistently taken this view of standing. And, of course, where individual rights or privileges are being sought, the position is a fortiori the same. ${ }^{199}$ Similarly, for the purposes of the recommended complaint procedures any mandatory federal grant standard may provide the basis for a complaint by persons adversely affected by the actions of the grantee or by the grantor agency's funding decisions.

Finally, in order to determine whether there is an adequate basis for complaint concerning a grantee's or potential grantee's compliance with federal standards, affected persons need to have access to both grantor and grantee program materials in the same place and the same form. Hence, the efforts of federal agencies to disseminate federal program materials should parallel those required for grantees in making the latter materials accessible.

Requirements for Grantees-Grant conditions merely requiring that a grantee make its program materials accessible will not necessarily be sufficient to discharge the grantor agency's obligation to ensure that affected persons are adequately informed. Different types of programs minister to the needs of different chenteles and require different techniques for effective communication. Many grantor agencies already recognize this problem and are experimenting with creative approaches to the dissemination of public information.

The Social and Rehabilitation Service in HEW, for example, has extensive public information regulations specifically desigued to facilitate the utilization by welfare recipients of a state's fair hearing procedure for resolving complaints. SRS requires that state plan materials in the form of program manuals and other statements of agency policy

19635 Fed. Reg. 6322 (1970).

197397 U.S. 159 (1970).

198270 F. Supp. 650 (S.D.N.Y. 1967).

199 E.g., Thorpe v. Housing Authority, 393 U.S. 268 (1969). 
affecting the public be maintained in the state office and each local or district office and be available to the public through custodians. ${ }^{200}$ SRS further requires that states give specific notice to welfare applicants or recipients, both at the time of initial application and at the time of any subsequent action concerning the applicant or recipient's case, of the existence of the fair hearing procedure. ${ }^{201}$

The FHWA relies heavily on public hearings as a technique for disseminating public information. While there has been a great deal of criticism of these public hearings, it has largely been with reference to their utility as a device for public participation in decision-making. Certainly the public hearing is a far better informational device than mere newspaper advertisements, and the affected public is usually too large to give fully effective individualized notice of proposals for projects. Under present procedures applicable to location hearings, for example, ${ }^{202}$ the state highway department must publish notice of a proposed hearing in local newspapers and mail copies of the notice to all public officials and citizen groups that have requested notice of highway department hearings or that "by nature of their function, interests or responsibility the highway department knows or believes might be interested" in the proposed project. ${ }^{203}$ The notice must contain a description of the proposed project and specify that maps, drawings, and other pertinent information developed by the state highway department are available at a convernent location in the vicinity of the proposed project. ${ }^{204}$

Despite their clear informational value, even these procedures can be improved. For example, while highway departments must provide

200 Custodiaus must request the material, be centrally located and accessible to a substantial portion of the recipient population, and agree to accept responsibility for filing all amendments and changes forwarded by the agency. These custodians are: libraries, local offices of the Bureau of Indian Affairs, legal service organizatious, and organizations of welfare recipients. 45 C.F.R. $\$ 205.70$ (1971).

20145 C.F.R. $\$ 205.10$ (a) (92) (1971). Synopses of decisions in previous fair hearings must also be made available to the public. 45 C.F.R. $\$ 205.10$ (a) (16) (1971). It is not clear, however, whether these materials are to be maintained and made available in the same manner as the grantee's regulations and other statements of agency policy.

202 Federal Highway Administration, Policy and Procedure Memorandum 20-8 [hereinafter cited as PPM], 23 C.F.R. $\$ 1.38$, App. A (1972) requires state highway departments to hold two public hearings on most federally aided highway projects. There must be an initial corridor hearing on the social, economic, and environmental effects of the route location and then a design hearing on the effects of the highway design. The provisions applicable to both the corridor and the design hearings are virtually identical.

203 PPM 20-8, \$ 8(b) (2), 23 C.F.R. $\$ 1.38$, App. A (1972).

204 PPM 20-8, $\$ 8$ (a) (3), 23 C.F.R. $\$ 1.38$, App. A (1972). 
individual notification of hearings to persons requesting it prior to a location or design hearing, they are required only to publicize by newspaper notice that a decision has been made and transmitted to the FHWA for approval. ${ }^{205}$ Because this is the point at which aggrieved parties are most likely to wish to file a complaint and because there may be a significant interval between the public learing and a location or design decision, a more effective means of publicizing these decisions seems desirable.

The FHWA also provides the public access to information by means other than public hearings. For example, DOT's new regulations under the Uniform Relocation Assistance and Land Acquisition Policies Act ${ }^{208}$ require a state highway department (1) to present its relocation program at all public hearings on a highway project, (2) to prepare brochures on its relocation program, (3) to announce publicly its relocation program through appropriate mass media, (4) to post notices on the relocation program in or on buildings to be acquired, and (5) to mail by certified mail individual notices on the relocation program to all persons to be displaced. Displacees are also to be informed of their rights to relocation assistance and payments and to appeal any adverse determination on their eligibility for relocation payments or the amount thereof to the head of the state agency. ${ }^{207}$ The information system is thus designed to facilitate the use of the grantee's complaint procedure.

The present practice of the Federal Highway Administration suggests another public information problem to which agencies should give attention. The system of project grants tends to presume that information has been made available on the local level at an early stage in the development of the project through the local planning process. In programs like federal aid for highways, the application by a state highway department for program approval, the first step in the funding process, comes to the FHWA with the imprimatur of state and local assurance that the project conforms to local and statewide planning and that environmental considerations have been addressed in at least a preliminary form. Attached to each initial application must be documentation indicating that the Bureau of the Budget A-95 review procedure has been followed, ${ }^{208}$ that is, that the proposed program has been referred to and received by a wide range of state and local officials.

205 PPM 208, §§ 10-11, 23 C.F.R. $\$ 1.38$, App. A (1972).

20642 U.S.C. $\$ 3307$ (1970).

20749 C.F.R. $\$$ 25.83-25.93 (1972).

208 See generally, Intergovernmental Information Act of 1968, 42 U.S.C. $\$ 4222$ (1970). 
Unless issues such as needs of the localities, conformity with local planning, or environmental, economic, or social concerns are raised by state or local officials, the FHWA will not raise these questions at the application stage nor seek to disseminate information on the project outside official channels. The FHWA's position is that since comments through the BOB A-95 review procedure come largely from elected officials of the states and locahties, affirmative comments or no comments should be taken as reflecting the public interest as determined through the appropriate political process. The FHWA is not in the business of reforming local government.

The FHWA's attitude, however, seems to miss the point that the federal-aid highways program has already "reformed" local government by vesting great political power in the state highway departments. If local officials, for this reason or for others, fail to provide the sort of critical review of projects which ensures conformity with the relevant federal standards, the FHWA should not thereby be relieved of its duty to ensure such compliance. In order for citizen complaints to aid significantly in that effort, it may be necessary for state highway departments and other project grantees to establish an information system which makes their plans accessible to all affected parties at an early stage of project planning.

HUD has taken measures to ensure that residents of an urban renewal area are able to obtain adequate information about urban renewal plans. A local public agency applying for an urban renewal grant must establish a Project Area Committee (PAC) to assist in the planning and execution of the urban renewal project. The PAC should consist of a fair cross section of the residents of an urban renewal area and should receive all information and reports on the project in advance of the time when decisions are made..$^{209}$

The procedures required of grantees by SRS, the FHWA, and HUD in some respects go beyond what is literally required by Part C, because that recommendation by itself does not require either public hearings or citizen participation. The procedures already required, however, indicate possible ways to implement the general principle stated in Part $\mathrm{C}$ within the framework of particular grant programs. Moreover, they suggest that even well-developed, existing informational devices may require modification in connection with the institution of a regularized complaint procedure.

209 Urban Renewal Handbook, RHA 7217.1. Until the Fall of 1970, PAC's were mandatory only in urban renewal projects whicb involved residential rehabilitation. They are now mandatory in all projects. 


\section{Range of Sanctions $s^{210}$}

The federal grantor agency should seek to develop an adequate range of sanctions for ensuring compliance with federal standards by grantees that apply for or receive federal financial assistance. The sanction of the total denial or cut-off of federal funds should be retained and used where necessary to obtain compliance, but the agency should have available lesser sanctions that do not result in the prevention or discontinuance of beneficial programs and projects. This range of sanctions should include in appropriate cases:

1. The public disclosure by the agency that a grantee lias failed to comply witl federal standards;

2. An injunctive action brought by the agency or the Department of Justice in the federal courts to require the grantee to fulfill any assurances of compliance with federal standards made by the grantee or to enforce the federal standards attached to the grant;

3. The disallowance as a program or project cost of an expenditure by the grantee that does not conform to federal standards or other partial denial of cut-off of funds that affects only that portion of a program or project that is not in compliance witl federal standards;

4. The imposition of special administrative conditions on grantee operations, including retroactive awarding of benefits, in order to ensure the reparation of any individual damage or prejudice or to correct any shortcomings in the effectuation of federal policy which have resulted from failures to comply with federal standards; and

5. The transfer of a grant, or the awarding of subsequent grants under the same or related grant-in-aid programs, to a different grantee if the original grantee violates federal standards.

Where an agency lacks statutory authority to invoke one or more of the above sanctions and such authority would provide an appropriate means of ensuring compliance with federal standards in a grantin-aid program administered by the agency, it should seek the necessary authority from Congress.

The agency should also consider the provision of incentives, such

210 The administrative Conference has altered $\mathrm{D}(1)$ and $\mathrm{D}(4)$ :

1. The public disclosure by the agency of a grantee's failure to comply with federal standards and an indication of the steps believed by the agency now to be appropriate.

4. 'The imposition on a grantee who has not complied with federal standards of additional administrative requirements specially designed to assure that the grantee brings its operations into compliance with federal standards and redresses the effects of past nonconpliance.

Administrative Conference of the United States, Recommendation 31, EnForcement of Standards in Federal Grant-in-Aid Programs (adopted December 7, 1971). 
as the contribution of an increased matching share or the awarding of additional grant funds, to grantees who comply with certain federal standards. Where the agency lacks statutory authority to provide an appropriate means of ensuring compliance with federal standards in a grant-in-aid program administered by the agency, it should seek necessary authority from the Congress.

\section{The Federal Complaint Procedure and the Imposition of Sanctions}

Should the federal agency determine that a complaint directed at a grantee submission or a grantee practice is not valid, it naturally will take no action on the complaint. The complainant has no further federal administrative remedies and may pursue any judicial remedies available. The situation is more complicated if the agency determines that the complaint is valid. The issue then becomes, how should the federal agency achieve compliance with federal standards. The agency should, of course, inform the grantee of its determination and seek to persuade the grantee to comply with federal standards. If these efforts prove unsuccessful, the federal agency should consider the imposition of one or more of the range of sanctions delineated in Part D.

The proposals in this Article distinguish between the disposition of complaints and the imposition of sanctions for violations of federal standards. In other words, the federal agency's determination that a complaint is valid does not automatically result in the imposition of a sanction, unless, of course, the relevant statute leaves the agency no discretion. This distinction between the complaint procedure and the enforcement machinery is desirable for three reasons. First, the federal agency should not limit its enforcement machinery to instances of private complaints but should invoke it also where the agency's own investigations uncover violations of federal standards. Second, the federal agency should have broad discretion to choose the appropriate sanctions to invoke. The purpose of providing the agency with a range of sanctions is to permit it to make a flexible (but effective) response to instances of noncomphance. Finally, the enforcement process should be structured to protect the rights and interests both of the grantees and of all the beneficiaries of the grant-in-aid program. The complaint process, on the other hand, should be structured to afford a fair liearing to the complainant on his grievance.

The distinction between the disposition of complaints and the imposition of sanctions avoids interference with and unnecessary use of 
procedures otherwise required for the latter action. Prior to the partial or total discontinuance of federal funding, a grantee or noncomplaining beneficiary of a program may have a statutory or constitutional right to a hearing involving formal procedures not employed in the agency's complaint process. For example, statutes establishing formula grants to the states for social assistance programs provide that HEW must hold a conformity hearing prior to terminating a state's grant. ${ }^{211}$ Affected private parties have standing to intervene..212 While governmental grantees may not be "persons" entitled to such a hearing under the due process clause of the fifth amendment in cases where there is no statutory right to a hearing, ${ }^{213}$ private grantees may have a due process right to a hearing prior to the termination of a grant. ${ }^{214}$ Of course, the federal agency may avoid duplicative hearings by combining the hearing it affords the complainant with the hearing it must afford the grantee prior to the imposition of a sanction. This approach is likely to be appropriate when the complaint raises factual issues which should be aired at a public hearing.

Where complaints are directed at a grantee's submission, it may not be possible to separate a finding of noncompliance from the imposition of sanctions. Once an agency determines that the complaint is valid and that the submission does not meet federal standards, the agency may simply disapprove the submission and withhold federal funds. The agency's decision on the complaint is thus the basis for the agency's funding decision. In many instances this is no doubt for the best. If a grantee's initial application for a project grant does not meet federal standards, the federal agency should not approve it nor fund the project unless the grantee brings the application into conformity with federal standards. Likewise, if the agency must make an affirmative finding that an existing project complies with federal environmental or relocation standards, the agency cannot make a contrary finding and permit the project to continue. In these cases the agency's determination that a complaint is valid necessarily affects the agency's decision to deny or terminate federal funding for the project.

More flexible responses by the federal agency are appropriate in other areas. For example, amendments to state plan material in formula

211 See, e.g., 42 U.S.C. $\$ 604$ (1970) (AFDC).

212 National Welfare Rights Organization v. Finch, 429 F.2d 725 (D.C. Cir. 1970).

213 South Carolina v. Katzenbach, 383 U.S. 301, 323-24 (1966).

214 Aquavella v. Richardson, 437 F.2d 397 (2d Cir. 1971) (private nursing home that provides services under the medicare program entitled to judicial review of termination proceedings). 
grant programs become effective upon submission to the federal agency. If the federal agency determines that the amendment does not conform to federal standards, the agency should seek to obtain compliance with federal standards through education, persuasion, and, if necessary, the imposition of one or more of a range of sanctions. Mere disapproval of the amendment will have little effect unless the federal agency acts affirmatively to obtain comphance. Since the grant program is already funded and in operation, the termination of federal funding through a conformity proceeding may not be the most appropriate sanction; the federal agency should consider alternative sanctions, such as publicity, an action seeking an injunction, or audit exceptions.

Although applications for project grants are generally not funded until approved-and there is a time gap between submission and approval-the mere disapproval of a noncomplying application often does not resolve the enforcement problem. Many project grants, such as grants for highway construction, are approved in stages, and substantial amendments to project applications are common in urban renewal and related programs. If the federal agency disapproves an amendment to an application or an application for a later stage of an ongoing project, it in effect terminates funding in midstream. It would seem appropriate for the federal agency to consider alternative sanctions if it cannot persuade the grantee to revise its submission to conform with federal standards.

\section{Part $D(1)$}

This part proposes that in appropriate cases the federal agency publicize a grantee's noncompliance with federal standards. The use of publicity as a sanction should prove most effective when coordinated with the federal administrative complaint procedure proposed in Part A. The implementation of that procedure should put grantees on notice that the federal grantor agency is serious about its enforcement responsibilities, and the publicity generated by individual complaints and by any public proceedings held by the federal agency on the complaints is likely to induce compliance. Compliance is particularly likely to result if the federal agency publicizes a strong, well-reasoned decision that the plan, application, or practice under attack violates federal standards. The grantee may, decide that the wiser course is to comply with the federal agency's view of the law, or it may attempt to take the matter to court and comply with the eventual ruling of the court. In neither case is there an interruption in the federally assisted program. 
Part $D(2)$

Part $D(2)$ proposes that in appropriate cases the federal agency or the Department of Justice sue in the federal courts to compel a grantee to observe federal standards. Suits for injunctive relief are a potentially effective sanction for enforcing federal standards in grant-in-aid programs. Grantee officials are likely to respect any decree issued by. a court ordering them to comply with federal standards, and if they do not obey such a decree, they may be held in contempt of court.

The legal basis for enforcement suits of this type is clearly established. The Supreme Court has on several occasions upheld suits by the Umited States to enforce statutory conditions attached to grants of public land. ${ }^{215}$ A specific grant of authority to the Attorney General is not required in order for him to sue to enforce the conditions of a grant, since the Attorney General may sue on behalf of the United States whenever the Umited States has an interest to protect. ${ }^{216}$ That interest in these grants cases is a contractual one. ${ }^{217}$ Therefore, "the acceptance by the recipient of the grant to which the conditions and stipulations are attached creates an obligation to perform the conditions on the part of the recipient." 218 Similarly, the United States may sue to enforce specific assurances of compliance with federal standards made by grantees of federal financial assistance. For example, suits have been brought by the Department of Justice to force southern school districts to implement the school desegregation plans filed with HEW under Title VI of the Civil Rights Act of 1964 as a condition for receiving federal aid. The Department of Justice may institute these suits without satisfying the procedural prerequisites for school desegregation suits under Title IV of the same Act. ${ }^{219}$

The Department of Justice recently turned to injunctive relief in a suit against the State of Alabama to force various state agencies administering a large number of categorical assistance programs to recruit, hire, promote, and demote their employees on a merit basis without discrimination on the ground of race or color. ${ }^{220}$ The state agencies in Alabama had refused to give adequate assurances that they would ob-

215 United States v. San Francisco, 310 U.S. 16 (1940) (grant to a municipality); Oregon \& Cal. R.R. v. United States, 238 U.S. 393 (1915) (grant to a railroad); McGee v. Mathis, 71 U.S. 143 (1866) (grant to a state).

216 Wyandotte Transportation Co. v. United States, 389 U.S. 191 (1967).

217 McGee v. Mathis, 71 U.S. 143 (1866).

218 United States v. Frazer, 297 F. Supp. 319, 322 (M.D. Ala. 1968).

219 United States v. Board of Educ., 295 F. Supp. 1041 (S.D. Ga. 1969).

220 United States v. Frazer, 297 F. Supp. 319 (M.D. Ala. 1968) (Johnson, C.J.). 
serve a merit system, but they were nevertheless receiving federal funds in large amounts. The Department of Justice sued to enforce the conditions attached to those funds. Alabama argued that the statutory procedures for withholding funds in cases of noncompliance with federal standards was the exclusive remedy available to the United States. The court disagreed and denied the state's motion to dismiss the complaint:

This Court is clear to the conclusion that the United States does have standing to seek judicial enforcement of the terms and conditions of grants of Federal property and that the administrative remedy of termination of assistance was not intended to be and is not exclusive. The argument of the State, if it prevailed, would necessitate this Court's telling the United States of America that the only remedy it had in this case would be to administratively terminate the Federal funds of $\$ 150,000,000$ a year provided to the State agencies here concerned for assistance to the aged, to families with dependent children, to crippled children's services, for aid to the blind, aid to the permanently and totally disabled, and for other similar programs administered by the defendants for the benefit of United States citizens residing in the State of Alabama. ${ }^{221}$

Part $\mathrm{D}(2)$ recognizes that enforcement actions in the federal courts are not appropriate sanctions in all cases. When a federal agency encounters noncompliance, it should consider whether court enforcement is an appropriate and effective sanction. If judicial enforcement is not likely to bring prompt comphance, the agency should invoke one or more of the remaining sanctions mentioned in Part $\mathrm{D}$, including a total fund cut-off in cases where the imposition of that sanction is necessary to obtain compliance. Howvever, court enforcement has not been utilized enough in the past, and agencies have relied too heavily on administrative cut-off of funds to offending grantees. Recent social legislation recognizes this and makes explicit a means of judicial enforcement of federal standards. In particular, the Nixon Administration's bill establishing a Family Assistance Plan, provides that if "the Secretary determines that a State plan which he has approved ... no longer complies with the applicable requirements for approval, or that in the administration of such plan ... there is a failure to comply sub-

221 Id., at 322. Chief Judge Johnson subsequently ruled in favor of the United States on the merits, finding that the state agencies involved had engaged in massive discrimination in employment. United States v. Frazer, 317 F. Supp. 1079 (M.D. Ala. 1970). He then entered a broad remedial order which has been appealed by the state to the Fifth Circuit Court of Appeals. 
stantially with any provision of such plan or agreement, the Secretary may request the Attorney General to bring suit to enforce the provisions of such plan or agreement." 222

An advantage of judicial enforcement is the flexibility inherent in an equity decree. A federal judge may fashion an equity. decree that provides effective relief from past illegality and prevents future illegality without requiring a fund cut-off. An agency may not have power to require affirmative action by grantees but can only manipulate to a greater or lesser extent the purse strings. A court, on the other hand, can fashion affirmative relief to undo the effects of past discrimination and to order compliance in the future. This task is a delicate one, and the federal agency that has expertise in the area should assist the court in formulating the injunction. That agency can assist the Department of Justice in enforcement actions brought by the United States and can participate as an amicus curiae in actions brought by private parties to enforce federal standards. Agencies should assign high priority to this task. The result may be that beneficial state and local projects will continue to function but will be restructured by the court decree to comply with federal standards. ${ }^{223}$

\section{Part $D(3)$}

This part recognizes that partial cut-off of federal funds, limited to

222 H.R. 16311, October revised revision, 91st Cong., 2d Sess., \$ 407 (g) (Nov. 5, 1970). Judicial enforcement of federal standards in formula grant programs may have effects similar to those of an administrative fund cut-off. Implicit in a court order to comply with federal statutory standards is the condition expressed by the words, "so long as you accept federal grant-in-aid funds." In Rosado $\nabla$. Wyman, 397 U.S. 397, 420-22 (1970), the Supreme Court instructed the district court to grant the state an interval in wbich to achieve compliance or to withdraw from the program. The option was allowed because compliance without some reordering of the New York benefit provisions would cost the state $\$ 40,000,000$ per year. In most project grants, however, the grantee may not have the option to withdraw from the federally funded program because he has contractually bound himself to complete the project. In these cases an injunction and a fund cut-off have different effects; the injunction can simply order the state to comply with federal standards.

223 Gautreaux v. Chicago Housing Authority, 296 F. Supp. 907 (N.D. Ill. 1968) indicates the possible consequences if agencies do not cooperate with the courts to fashion remedies in enforcement actions. HUD's participation in that litigation has been criticized as ineffective. Its memorandum on the "appropriate remedy" was "vague" and apparently delivered to the district judge on the evening before he issued the injunction. The injunction itself was drafted entirely by the plaintiff's attorney, who had no expertise in the housing area, and reflected a serious lack of understanding of the problems of urban housing and development. It may therefore prove ineffective to accomplish integrated public housing in Chicago. Comment, Public Housing and Urban Policy: Gautreaux v. Cbicago Housing Autbority, 79 YaLE L.J. 712 (1970). 
that pörtion of a federally assisted program that is not in compliance with federal standards, may persuade a grantee to comply with federal standards. A partial fund cut-off does not bring the whole program to a halt and is thus likely to hurt fewer innocent beneficiaries of the program than is a total fund cut-off. Congress recognized this in the Social Security Amendments of 1967 when it amended various sections in Title 42 to authorize the Secretary of HEW to limit his withholding of federal funds to that part of a state plan with which authorities were not complying. ${ }^{224}$ Thus, if a state is not actually providing certain söcial services on a statewide basis, but is only providing them in certain geographical areas, HEW may withhold the federal funds which support those services while continuing the fiow of federal funds for the remainder of the social assistance program. ${ }^{225}$

Federal grantor agencies may effectuate a partial fund cut-off in a number of other ways that do not require specific statutory authority. The most common method is the disallowance as a program or project cost of an expenditure by the grantee that does not conform to federal standards. This technique builds on the distinction between conformity requirements and matching requirements. Conformity requirements are those standards which grantees must meet in order to be eligible for federal grants. Matching requirements are those standards which grantees must observe in expending money in order to receive the federal share of the costs incurred. The federal share of total grant costs varies with the grant program and may be anywhere from thirty per cent or less up to one hundred percent. If the requisitions submitted by the grantee or other evidence uncovered by the federal agency indicate that the grantee is incurring costs that are improper, the federal government should not recognize these expenditures as program or project costs and shonld not release the federal funds to pay for them.

Normally, matching problems arise at the audit stage, and the partial fund cut-off by the federal agency takes the form of an audit exception to a particular expenditure by the grantee. The clearest case for an audit exception is an expenditure by the grantee for a pur-

\footnotetext{
224 S. Rep. No. 774, 90th Cong., 1st Sess. (1967); U.S. Code Cong. \& Ad. News 2834, 3006 (1967).

225 There is some doubt, whether these amendments authorize HEW to withhold funds from a particular geographic locality in a state where a local agency is not complying, with federal standards. Statutes applicable to other formula grant programs, however, specifically authorize the federal agency to withhold federal funds from one locality. while continuing the flow of federal funds to other areas of the state. See grants under Title I of the Elementary and Secondary. Education Act of 1965, 20 U.S.C. $\S 241(1970)$.
} 
pose outside the scope of the categorical assistance program which the grantee seeks to qualify as a program or project cost. A unit of local government, for instance, cannot normally designate expenditures on highways as project costs for an urban renewal project. Audit exceptions are also common when a particular expenditure by a grantee violates federal standards. If HEW auditors discover that a state welfare administration has aided a dependent who is over the age limit set by federal law for the provision of aid under AFDC, HEW will decline to share the cost of paynients to that dependent. HEW thus treats the state agency's noncompliance with federal law as a matching question rather than as a conformity question. In this way audit exceptions may be used on a large scale against a whole class of recurring expenditures in an effort to change a nonconforming policy or practice.26 At a certain point, of course, the state's noncompliance with federal standards may become so substantial as to raise a conformity issue that calls for a direct withholding of federal funds. The question of when that point is reached is a determination generally left to the judgment of the grantor agency. ${ }^{227}$

The principal objection to audit exceptions as a device for achieving compliance with federal standards is their post-hoc nature. The grantee has already received federal funds and has expended them in violation of federal standards. Remedial action may come too late and may depend on the thorougliness of the audit. And not all grantee activities are audited. These difficulties can be overcome if the federal agency. announces ahead of time that it will no longer recognize as project costs certain types of expenditures by a grantee until the grantee complies with federal standards.

In administering urban renewal grants HUD occasionally exercises this advance notice to effect a partial fund cut-off. When HUD discovers that a recipient of an urban renewal grant is not observing federal standards for relocation or land acquisition, HUD nray simply tell the grantee not to spend any more money for demohition or land acquisition activities until the matter is cleared up. If the grantee does continue to spend money for these purposes, the expenditures incurred will not be treated as project costs for which the federal government must provide its matching share. This partial fund cut-off allows the remainder of

$226 \mathrm{M}$. Derthick, The Influence of Federal Grants: Public Assistance in MassaCHUSETTS 23, 208 (1970).

227 Id. at 23-24. 
the urban renewal project to continue. ${ }^{28}$ Alternatively HUD occasionally informs an LPA that its administrative expenses will no longer be recognized as project costs until federal standards are complied with. Such action is potentially effective. The execution of the project continues, and the partial fund cut-off endangers principally the salaries of the local administrators who are thus provided with a strong incentive to comply with federal standards.

The manner in which urban renewal projects are funded reduces the effectiveness of the partial fund cut-off and demonstrates the difficulty of fashioning effective sanctions to meet the different needs that face the various agencies. The amount of the federal grant, which is initially determined when HUD approves a survey and planning application, is either sixty-six and two-thirds percent or seventy-five percent of net project costs. Net project costs may roughly be defined as gross or total project costs less the proceeds to the LPA from selling project land to redevelopers. Following HUD's approval of an LPA's survey and planning application, HUD awards the LPA a grant reservation equivalent to the amount of the grant and then advances federal funds to the LPA for planning the urban renewal project. If the LPA is successful in obtaining a loan and grant contract, HUD then provides the LPA with operating capital to execute the project, either by lending money directly to the LPA or by guaranteeing the LPA's project notes which are sold on the private money market. Every three or six months the LPA presents HUD its requirements for operating capital and for paying off any project notes due. HUD normally meets those requirements by increasing the LPA's loan authorization but may, as the project progresses, make a partial or project payment on the grant. Since the proceeds of land disposition are not available to the LPA until a comparatively late stage in the project, the LPA receives from HUD in the form of loan authorizations and project payments the equivalent of gross project costs. Most LPA's incur heavy land acquisition and demolition expenses at an early stage in the project and thus enjoy for the greater portion of the project's duration loan authorizations substantially in excess of the grant reservation. Under those circumstances a threat to withhold funds is somewhat empty, because the LPA already has the funds. If the LPA terminates the project, the federal government is already liable for more than the grant reservation.

228 In appropriate cases, HUD restricts its fund cut-off to demolition and land acquisition activities on a particular block in a project or with respect to a particular building. 
Despite these peculiarities in the funding of urban renewal projects, the partial fund cut-off may still serve as an effective sanction. To obtain loan authorizations or project payments at three or six month intervals, the LPA must itemize its cash requirements for project costs for each budget line item. If certain costs are not recognized at this point as project costs, the amount of the loan authorization or project payment is reduced by what would have been the federal share, and the locality must absorb the entire costs. The flow of federal assistance is at least decelerated. Since LPA's generally desire to complete urban renewal projects as promptly as possible, this slow down should encourage them to comply with federal standards. Furthermore, until they do so they are forced to absorb the full cost of certain expenditures. HUD, of course, enjoys much greater leverage when urban renewal activities are funded on an annual-increment basis under the Neighborhood Development Program. Although an LPA's loan authorization at a given point in an action year may exceed the increment for that year, HUD has not committed itself on the annual increments for the following years. Where particular activities by a LPA violate federal standards, the costs budgeted for those activities should be disregarded when computing the LPA's annual increment.

\section{Part $D(4)$}

One of the advantages of the use of a suit to enjoin grantee action inconsistent with federal standards is the flexibility of a decree in equity. The court may issue orders both prohibitory and mandatory and, through careful choice of remedial action, may achieve compliance with federal standards without disrupting ongoing programs. Part $D(4)$ suggests that similar powers be exercised by federal grantor agencies where they are available and that they be sought in appropriate cases by agencies which do not presently have such powers. Indeed, the imposition of special administrative requirements or conditions on noncomplying grantees combines the flexibility of the equity decree with agency expertise in administration.

Often an agency which administers project grants will have discretion to impose special conditions on grantees. A legal services grant might, for example, be conditioned on the performance of particular law reform activities. Such a condition could be imposed at the beginning of federal funding or at the time of the grant's annual renewal, should the agency determine that the grantee's performance has been 
deficient. In the latter case it would be a special administrative condition of the type recommended here.

In certain formula grant programs the existence of the special condition sanction may be necessary to remove disincentives to voluntary compliance. For example, HEW has recently made a serious effort to enforce section 402(a) (23) of the Social Security Act, ${ }^{229}$ which requires that states update the standards of need in their AFDC programs. Because out-of-date standards of need are usually undervalued, the recalcitrant grantee has every reason to prolong negotiations and the rendering of a final decision. Every day's delay may represent a substantial saving of state funds.' Were the federal agency empowered to require retroactive adjustments in the payments to individual beneficiaries in appropriate cases, its enforcement position would be enormousily strengthened.

Additional uses for the flexible administrative sanction can easily be enumerated in the area of public assistance. Special eligibility procedures might be required in those local welfare departments that discourage applications. Special training programs might be required to upgrade the abilities of service personnel. In extreme cases HEW might require the state to administer a local welfare program directly until the local office's operations were regularized or to institute proceedings to remove certain personnel for cause. Similar suggestions could be made for other continuing grant programs ranging from public housing to employment services to pubhic highway construction. Section 521 of the Nixon-Mills Family Assistance Plan $^{230}$ would provide the Secretary of $\mathrm{HEW}$ with the necessary authority to take actions similar to the ones mentioned above, upon finding noncomplance with federal standards.

Even without special legislative authority, grantor agencies may find that they have authority to impose limited special administrative sanctions. Virtually all agencies, for example, have authority to require reports concerning the operations of their grantees. Where a federal grantor agency has determined that a grantee is not in compliance with a federal standard, it might require the grantee to report specially to it concerning that aspect of the grantee's program. Such reports would be designed to allow the federal agency to monitor more carefully the grantee's activities in that particular area and to assure thereby that compliance is achieved.

229 See, e.g., Arizona State Dep't of Pub. Welfare v. HEW, 449 F.2d 456 (9th Cir. 1971); Connecticut State Dep't of Pub. Welfare v. HEW, 448 F.2d 209 (2d Cir. 1971). 230 H.R. 1, 92 d Cong., 1st Sess. (May 26, 1971). 


\section{Part $D(5)$}

This part proposes the transfer of a grant, or the awarding of subsequent grants, to a different grantee if the original grantee violates federal standards. Such action may not be feasible in the case of large formula grants administered by the states, but it is often appropriate in the case of project grants. Project grants normally last for a limited number of years, and grantees commonly apply for a renewal of the grant or for a new grant under the same or a related grant program. In these situations Part $\mathrm{D}(5)$ proposes that the grantee's past nonobservances of federal standards be taken into account. Part $D(5)$, which in effect penalizes the grantee for his past noncompliance with federal standards, is the counterpart to the final paragraph in Part D, which proposes incentives for rewarding grantees who successfully comply with federal standards.

Federal grantor agencies presently consider a grantee's past performance when deciding upon new applications for project grants, but this is generally done internally and on an ad hoc basis. An LPA that has successfully run one or more urban renewal projects stands a better chance of obtaining the regional office's go-ahead for new projects than does an LPA with a poor record. An LPA with a poor track record often encounters delays and lack of interest when it starts to work with the regional office staff on the selection of another urban renewal area and on the preparation of a Survey and Planning Application. Part $\mathrm{D}(5)$ and the provision for compliance incentives should encourage federal agencies to formalize this process and to focus their review of past performance on the grantee's compliance with federal standards. The complaints procedures established under Parts A and B should provide a source of relevant data concerning the grantee's compliance with federal standards. If there have been no complaints that a grantee violated federal standards, or if the complaints liave been resolved in the grantee's favor, then the grantee should receive some recognition for its achievement. On the other hand, if there have been complaints, and if the federal officials designated to resolve the complaints have found that the grantee has violated federal standards, then the grantee's past violations should be a factor weighing against approving its present application. In extreme cases, the grant conld be transferred in midproject to a new grantee.

The formality which should accompany the operation of complaint procedures should alleviate the dangers that grantees will lose federal: funds for political reasons or because of community disapproval of 
a project's goals or accomplishments. These dangers have on occasion in the past proved real. ${ }^{231}$ To some extent such dangers will always accompany a system of discretionary grants-in-aid. The development of formal procedures that focus on the grantee's compliance with federal standards should contribute to a lessening of these dangers.

\section{Other Possible Sanctions}

There are other sanctions, in addition to those recommended, which might be used to enforce federal standards. The following is a list of those which were considered by the authors but rejected:

1. Congress might pass a statute providing that state or local officials who wilfully violate federal standards in the administration of a federal grant would be guilty of a civil or criminal offense and subject to fine or imprisonment. Alternatively, the federal grantor agency could administratively rate state or local officials on the basis of compliance with federal standards in the programs they administer. These ratings could affect the career opportunities of these officials and thus influence their conduct.

2. Congress might pass a statute providing for the removal from office of state and local officials who violate federal standards in the administration of a federal grant.

3. Congress might provide by statute for the federal takeover and operation of state and local programs receiving federal financial assistance which consistently violate federal standards.

4. Congress might provide by statute that a fund be set aside from the general revenues which would be apportioned and distributed annually among the states on the basis of population. Federal funds withheld from a state for noncompliance with federal standards in federally assisted programs would be deducted from the state's share of this fund rather than from the federal funds available to the state in the federally assisted programs.

These sanctions are appealing because they are likely to be more effective than those proposed in Part D. On the other hand, the first three run strongly counter to modern notions of federalism and are unlikely to win widespread acceptance. They are simply too harsh and do too much to undermine the independence of state and local

231 See the description of OEO's refusal to renew a Head-Start grant to a group of poor Mississippi Blacks, in Cahn \& Cahn, The New Sovereign Immunity, 81 Hakv. L. REv. 929 (1968). 
government. It would seem far better for the federal government to scuttle the whole grant-in-aid approach and directly administer the programs involved than for the federal government to resort to these sanctions. These sanctions also raise difficult constitutional problems concerning the power of the federal government to interfere in the governmental affairs of the states. ${ }^{232}$

The fourth sanction is revenue sharing by the backdoor. The advantages and disadvantages of revenue sharing should be confronted directly and not in the context of fund cut-offs. However, if Congress does determine to institute a system of revenue sharing, number four may have merit. Any funds withheld from the state for noncomphance with federal standards should be deducted from the general revenues assigned to the state and not from the funds available to the state for the federally assisted program in which the violation occurred. This arrangement would assure the continuation of the program but at the same time would induce comphance with federal standards by tightening the purse strings. Local governmental units could be included in the enforcement mechanism if the system of revenue sharing adopted by Congress included the mandatory pass-through of funds to local government. Any funds withheld from units of local government for noncomphance with federal standards could be deducted from these passthrough funds.

\section{Compliance Incentives}

The final paragraph of Part D proposes to reward grantees who comply with federal standards as an alternative to penalizing those who do not. Compliance incentives are likely to take either of two forms. First, the federal government could increase the federal matching share or award an additional lump sum to grantees who fully comply with federal standards over a given period. Second, a grantee's compliance with federal standards on one project grant could be recognized formally as a positive factor when the grantee applied for another project grant under the same or a related program.

Incentives in the form of increased federal matching shares are already employed in formula grants for water pollution control and highway construction. The normal federal share for grants to municipalities to construct waste treatment facilities is thirty percent. ${ }^{233}$ This federal share will increase to forty percent if the state pays at least

232 See Oklahoma v. Civil Serv. Comm'n, 330 U.S. 127, 142-44 (1947).

233 Federal Water Pollution Control Act, 33 U.S.C. 1158 (b) (2) (1970). 
thirty percent of the costs of all such projects in the state. Alternatively, the' federal share, will increase to fifty percent if the state agrees to. pay. at least twenty-five percent of the costs of all projects within the state and to set enforceable water quality standards for the waters into which the projects discharge. Finally, the total federal grant for a project may be increased by ten percent if the project conforms to a comprehensive metropolitan plan. These incentives encourage metropolitan planning and the participation by the state in funding waste treatment plants and in setting and enforcing water quality standards. ${ }^{234}$ These incentives have had at least some effect and have been included in modified form in the Clean Air Act of $1970 .{ }^{235}$

The Federal Aid Highway Act of $1958^{236}$ provided similarly that states which agreed to control advertising alongside interstate highways would receive an incentive payment of one-half of one per cent of the cost of those portions of the system's projects to which national advertising control standards were applied. This incentive was reasonably successful; twenty-five states took advantage of it. ${ }^{237}$

An award of an increase in the federal matching share to grantees who observe federal standards probably cannot be implemented without Congressional action. Furthermore, such an incentive should only be used when compliance with federal standards is desirable but not essen-

234 See Note, Federal Programs for Water Pollution Control, 1 U.C.D.L. Rev. 71, 76-77 (1969).

235 Clean Air Act of 1970, 42 U.S.C. $\$ 1857$ (1969) (Supp. 1972).

236 Act of April 16, 1958, Pub. L. No. 85-381, §12 (c), 72 Stat. 96.

237 Advisory Comm'N on Intergovernmental Retations, I Fiscal Balance in the Federat System 62 (1967). The Highway Beautification Act of 1965, 23 U.S.C. $\S 131$ (1966), continued the incentive to conform and further provided that any state which did not effectively control, under federal standards, the erection and maintenance of outdoor advertising along the interstate and primary highway systems would lose ten per cent of its federal-aid highway allotment. An incentive grant was thus combined with a partial fund cut-off. This partial fund cut-off has not been successful. Apparently, twenty-nine states do not, at present, effectively control outdoor advertising and are therefore subject to the partial fund cut-off for noncomphance with the federal standard. Lamm \& Yasinow, The Higbway Beautification Act of 1965: $A$ Case Study in Legislative Frustration, 46 DeNver L.J. 437, 439 n 15 (1969). Enforcement of the fund cut-off has been deferred pending further study. Birmingham, Book Review, 70 Cox. L. Rev. 779, 783 (1970). The incentive approach therefore seems to have worked better than the partial fund cut-off. But the failure of the latter may be the fault of Congress, which has never appropriated any funds to pay the states the federal share (seventy-five per cent) of the cost of removing nonconforming billboards. Furthermore, the Department of Justice has interpreted the Act to require each state to pay. just compensation for the removal of offending billboards. This standard has worked hardship on many states which had maintained a right to remove billboards under the police power without paying for them. Lamm \& Yasinow, supra. 
tial. When compliance with a federal standard is considered essential by the federal government (as with nondiscrimination), incentives are not appropriate; grantees should not be allowed to purchase the privilege of not complying witl federal standards. 